\title{
1. LEG 162: NEW FRONTIERS ON PAST CLIMATES ${ }^{1}$
}

\author{
Eystein Jansen ${ }^{2}$ and Maureen E. Raymo ${ }^{3}$
}

\begin{abstract}
The North Atlantic Ocean and Nordic Seas represent one of the most climatically variable and sensitive regions on Earth. Our goal on Leg 162 was to recover sedimentary sequences with which to investigate the evolution of Northern Hemisphere climate on time scales ranging from hundreds to millions of years. These objectives required drilling rapidly deposited $(>50 \mathrm{~m} /$ m.y.) sequences, with triple APC coring to refusal. This approach allowed the retrieval of continuous sedimentary records for high-resolution analysis of the high frequency (orbital- and millennial-scale) components of the climate system. At the same time, these sequences also span the last few millions of years, an interval over which the average climate state has evolved toward generally colder conditions and over which the spectral character of orbital-scale variations has changed dramatically. Composite sections documenting continuous sedimentation were recovered at almost every site. These composites, many of which have sedimentation rates of over $10 \mathrm{~cm} / \mathrm{k} . \mathrm{y}$., are based on continuous and high-resolution discrete data obtained by the multisensor track (including magnetic susceptibility, natural gamma radiation, $P$-wave velocity, and GRAPE bulk density), as well as spectral reflectance measurements. This data typically has a temporal resolution of hundreds rather than thousands of years. These sites will provide the basis of ultra-high-resolution paleoceanographic studies of a key region in the global climate system for years to come.
\end{abstract}

\section{INTRODUCTION}

Understanding the causes and consequences of global climatic and environmental change is an important challenge for society. The high northern latitude oceans directly influence the global environment through the formation of permanent and seasonal ice cover, transfer of sensible and latent heat to the atmosphere, and by deepwater formation and deep-ocean ventilation which control or influence both oceanic and atmospheric carbon content. Thus, any serious attempt to model and understand Cenozoic variability of global climate must take into account climate processes occurring in this region. The rationale for Leg 162 is therefore based upon the importance of the Arctic and subarctic regions to the global climate and ocean systems. This is a region where much of the world's deep waters are formed with associated large regional ocean-atmosphere heat flux. Likewise, major amplification of climate changes can occur in this region due to snow and ice albedo feedbacks. In addition, the Arctic and the Nordic Seas region may play a key active role in the long-term evolution of global climate via linkages such as the effects of gateway openings on deep circulation, altered topography due to erosion and uplift, ocean carbon fluxes, ocean alkalinity, and atmospheric $\mathrm{CO}_{2}$. Linkages between deep-ocean circulation and atmospheric $\mathrm{CO}_{2}$ have already been proposed for late Pleistocene changes at glacial-interglacial time scales (e.g., Boyle, 1988; Broecker and Peng, 1989; Broecker et al., 1985).

Leg 162, which departed Leith, Scotland, on 7 July 1995, represents the second in a two-leg program designed to investigate three major geographic locations (the Northern Gateway region, the Greenland-Norway transect, and the Southern Gateway region), with the aim of reconstructing the temporal and spatial variability of the oceanic heat budget, the history of intermediate- and deep-water formation, and the history of glaciation on the surrounding land masses.

'Jansen, E., Raymo, M.E., Blum, P., et al., 1996. Proc. ODP, Init. Repts., 162: College Station, TX (Ocean Drilling Program). way.

Department of Geology, University of Bergen, Allégaten 41, N-5007 Bergen. Nor-

Department of Earth, Atmospheric, and Planetary Science, Massachusetts Institute of Technology, E34-254 MIT, Cambridge, MA 02139, U.S.A.
In combination with Leg 151, the Leg 162 sites are arrayed as broad north-south and east-west transects to monitor spatial paleoclimatic variability. In addition, a vertical array of sites in the North Atlantic, Sites 980 (FENI-1), 981 (FENI-2), 982 (NAMD-1), 983 (GARDAR1 ), and 984 (BJORN-1), monitors water-mass variability at the surface and at intermediate water depths. Site YERM-1 (not drilled due to ice conditions) and Site 986 (SVAL-1), deep drilling targets in the north, were planned to constrain the time of opening of the Fram Strait and water-mass exchange between the Atlantic and Arctic Oceans. The inception and history of high northern latitude glaciation are monitored on Sites 907 (ICEP-1), 985 (ICEP-3), 986 (SVAL-1), and 987 (EGM-4).

The first of these legs, Leg 151, was completed in 1993. The reader is referred to the Initial Reports (Myhre, Thiede, Firth, et al., 1995) for further information regarding sites drilled during Leg 151. Two of the objectives of that leg that were not achieved due to unfavorable sea-ice conditions were dating the opening of the Northern Gateway (Fram Strait) and the onset of glaciations in the Arctic. Leg 162 planned a return to the Yermak Plateau in an attempt to penetrate the glacial sedimentary package in this region. Unfortunately, sea-ice conditions were even less favorable than for Leg 151, and these plans had to be abandoned. The objective of documenting the glaciation history in the Svalbard-Barents Sea region was, however, successfully addressed by drilling Site 986 (SVAL-1) to almost $1000 \mathrm{mbsf}$, thereby penetrating all the glacial sequences. We also recovered two APC holes at Site 907 in order to develop composite sections at a site that was abandoned after drilling a single hole (due to a medical evacuation during Leg 151).

At Sites 980 and 981 (FENI-1 and -2), Site 983 (GARDAR-1), and Site 984 (BJORN-1), south of Iceland (Fig. 1), recovery of highaccumulation-rate sediments has provided the first records of oceanic variability on sub-Milankovitch time scales which extend beyond the last few glacial-interglacial cycles. These sections will allow the first studies of the evolution of millennial-scale climate variability in the North Atlantic over the last 5 m.y., and include investigations of past climate regimes significantly warmer than present. Site 982 (NAMD1) located at shallow depths on the Rockall Plateau (Fig. 2) will help reconstruct the water-mass behavior in the North Atlantic over the last $18 \mathrm{~m} . \mathrm{y}$. 


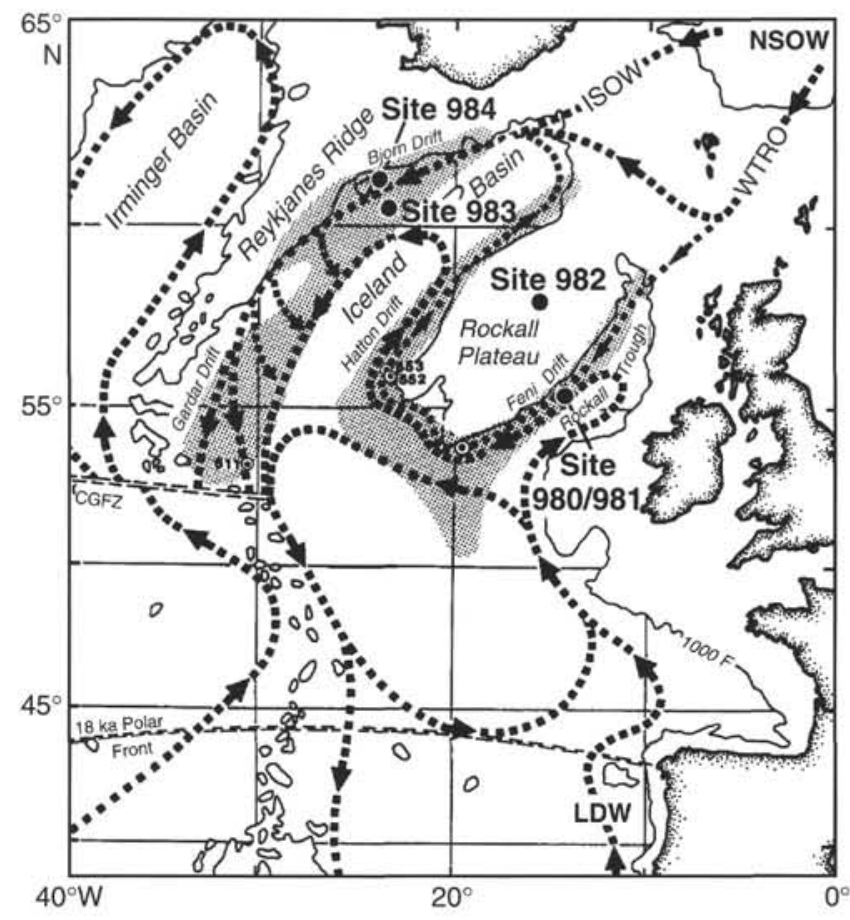

Figure 1. Map of North Atlantic showing major pathways of deep-ocean circulation and water masses, as well as areas of sediment drift accumulation. Also shown are Sites 980/981, 982, 983, and 984. NSOW = Norwegian Sea Overflow Water, ISOW $=$ Iceland-Scotland Overflow Water, WTRO = Wyville-Thomson Ridge Overflow, LDW = Lower Deep Water, CGFZ = Charlie-Gibbs Fracture Zone.

\section{REGIONAL PHYSIOGRAPHY AND PLATE TECTONIC EVOLUTION}

A more detailed in-depth description of the physiography and plate tectonics of the Nordic Seas and Northern Gateway is given in the Leg 151 Initial Reports (Myhre, Thiede, Firth, et al., 1995) and the reader is referred to this volume for further background information.

\section{Northern Gateway}

The bathymetry of the Nordic Seas and the Arctic Ocean is a reflection of the plate tectonic evolution of the area (Figs. 3, 4). The shallow ridge between Greenland, Iceland, and Scotland delimits the Nordic Seas to the south. North of this ridge, passive rifted and sheared margins surround the ocean basins, with three prominent marginal plateaus: the Vøring and Yermak Plateaus and the Morris Jesup Rise. The mid-ocean ridge defines the plate boundary between the American and Eurasian plates (Eldholm et al., 1990). Three regions separated by first-order ridge/fracture-zone systems can clearly be defined (Figs. 3, 4): a southern region between the GreenlandScotland Ridge and the Jan Mayen Fracture Zone, a central part bounded by the Jan Mayen and Greenland-Senja Fracture Zones, and a northern region (northern Greenland Sea) between the GreenlandSenja and Spitsbergen Fracture Zones. The transition zone between the Greenland Sea and Arctic Ocean has a very complicated tectonic evolution, which is reflected in the rough bathymetry of the area.

\section{Continental Margins}

The continental margins of the Nordic Seas and the adjacent Arctic Ocean are characterized by features typical of formerly glaciated shelves: deep shelves with breaks between 200 and 500 meters below sea level, longitudinal and transverse channels, banks, and depressions reflecting glacial erosion/deposition (Holtedahl, 1993). Glaciated shelves are commonly characterized by transverse channels originating from the major fjords. Trough mouth fans are often located outside these transverse channels. Sites 987 (EGM-4) and 986 (SVAL-1) were drilled at the lower slope of such fan complexes.

The Barents Sea Shelf, Svalbard Shelf, and East Greenland Shelf are transected by wide depressions extending to the 250 - to $400-\mathrm{m}$ deep shelf edge. Two prominent transverse features, south and north of Bear Island, appear as major drainage systems into the Lofoten Basin and Greenland Sea, with pronounced trough mouth fans. Smaller fans are located on the margin to the north and one was drilled as Site 986. Similar transverse channels with associated trough mouth fans are also located off the North Sea and off Scoresbysund Fjord in Greenland. The Scoresbysund Fan was drilled as Site 987.

The western part of the Fennoscandian landmass, the Barents Sea and Svalbard, were uplifted between 1000 and $2000 \mathrm{~m}$ in the late Tertiary and Quaternary, with deposition of extensive wedges of Pliocene and Quaternary sediments along the continental margins. It has not yet been determined if a coeval uplift took place along the East Greenland Margin. Key objectives of Sites 986 and 987 were to document the history of these wedges and how they relate to the glacial erosion and deposition.

\section{Iceland Plateau}

The Iceland Plateau is a shallow platform east of the Kolbeinsey Ridge, defined by the 1800-m contour and gently increasing in depth away from the ridge. To the north, the plateau is bounded by the western segment of the Jan Mayen Fracture Zone, separating the plateau from the deep Greenland Basin. The eastern part of the plateau slopes into the Norway Basin. Site 907 is located on the flat part of the plateau, while Site 985 is located on the slope toward the Norway Basin (Figs. 5, 6).

\section{Norway, Greenland, Lofoten, and Boreas Basins}

The Norway Basin (Fig. 3), is the deepest of the major basins in the Nordic Seas. It is bounded by the Greenland-Scotland Ridge, Iceland Plateau, the eastern Jan Mayen Fracture Zone, and the lower slope of the Norwegian Margin. A set of parallel seamounts, which represents the extinct Aegir spreading axis, active from Anomaly 24 to Anomaly 7 time transects the basin. Farther north, the Greenland and Lofoten Basins are situated symmetrically about the Mohns Ridge, both with well-developed abyssal plains. The Boreas Basin is separated from the Greenland Basin by the Greenland Fracture Zone. Its abyssal plain lies at approximately $3000-3200 \mathrm{~m}$, about $600 \mathrm{~m}$ shallower than the Greenland Basin.

\section{Plate Tectonic Evolution}

Major parts of the passive margins surrounding the Nordic Seas are parts of the North Atlantic Volcanic Province, which extends from the Charlie-Gibbs Fracture Zone at about $55^{\circ} \mathrm{N}$ to the Svalbard Margin at $75^{\circ} \mathrm{N}$. The volcanic rifted or sheared margins were formed in the early Tertiary (Hinz et al., 1991). The Norwegian and East Greenland Margins underwent a series of post-Caledonian extensional episodes in the late Paleozoic and Mesozoic before complete continental separation in the earliest Eocene. There has been a depositional area between Norway and Greenland since the Carboniferous with at least four distinct rift phases (Brekke and Riis, 1987; Larsen, 1987; Ziegler, 1988; Doré, 1991; Faleide et al., 1992). The igneous activity associated with the breakup and rifting at the Paleocene/ Eocene boundary had a profound influence on the structural and paleoenvironmental evolution of the North Atlantic region (Eldholm and Thomas, 1993).

The plate tectonic evolution of the Nordic Seas comprises two main stages (Talwani and Eldholm, 1977). From breakup (Anomaly 


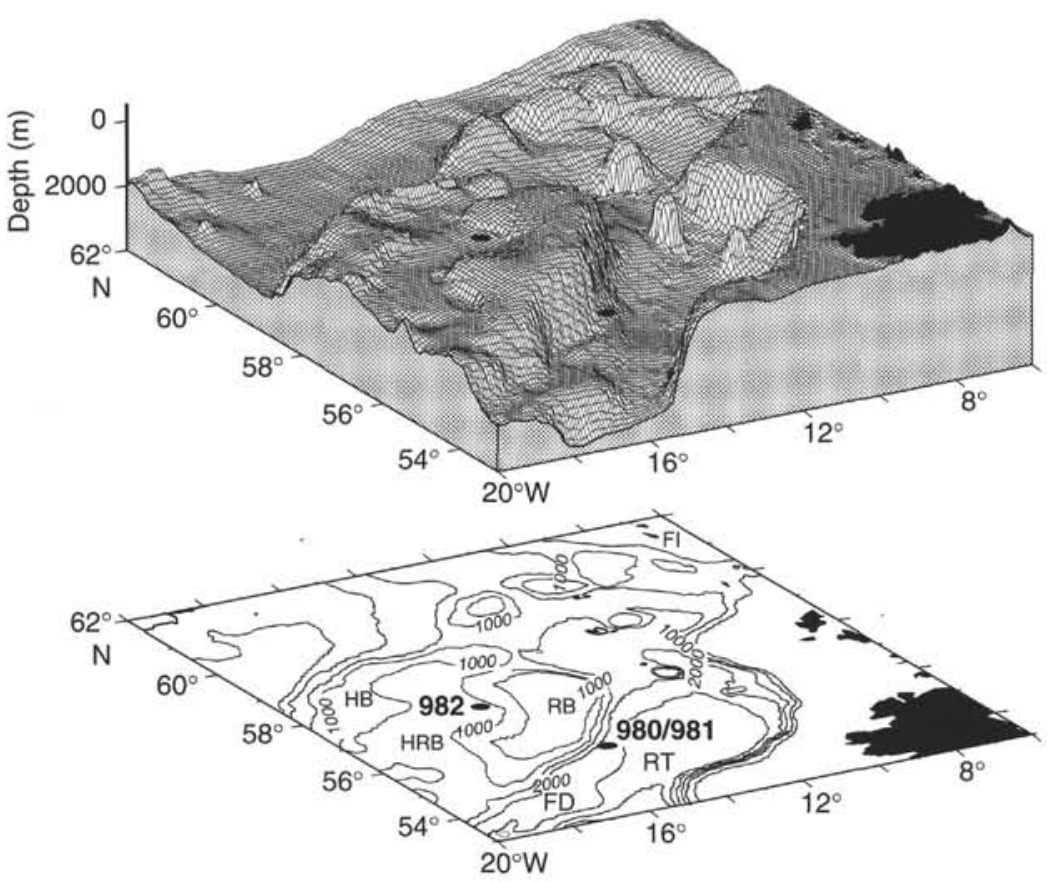

Figure 2. View of the Rockall Trough and Rockall Plateau showing location of Sites 980, 981, and 982. Flow from northeast is over the Wyville-Thomson Ridge. Land in southeast corner is Ireland. Physiographic features: FD = Feni Drift, FI = Faeroe Islands, HB = Hatton Bank, HRB = Hatton Rockall Bank, RB $=$ Rockall Bank, RT = Rockall Trough. Bathymetric data (in meters) from ETOPO5.

24R) and throughout the Eocene, Greenland moved as a separate plate in a northwesterly direction with respect to Eurasia. The northern Greenland Sea, however, had not yet started to open.

The area between the Greenland-Scotland Ridge and the Jan Mayen Fracture Zone evolved in a complex manner with a westward migration of the spreading axis away from the Norway Basin at about Anomaly 7 time, splitting off the Jan Mayen microcontinent from the East Greenland Margin (Fig. 4). The northern Greenland Sea also evolved in a complicated manner (Myhre et al., 1982). The presentday spreading axis is obliquely located close to the lower slope of the Svalbard Margin abutting the present plate boundary. The plate boundary between the Knipovich Ridge in the Greenland Sea and the Gakkel Ridge in the Eurasian Basin is a complex system of short spreading axis elements and transform faults (Fig. 3; Pour et al., 1985; Eldholm et al., 1990). Well-developed seafloor magnetic anomalies occur in the Norwegian Sea, the southern Greenland Sea, and the Eurasian part of the Arctic Ocean, whereas in the northern Greenland Sea a distinct seafloor spreading anomaly pattern is not observed (Fig. 4). When spreading in the Labrador Sea ceased in the early Oligocene, Greenland became included in the American plate, and the relative plate movements between the American/Greenland and Eurasian plates changed to a more west-northwest direction. This change in plate movement at Anomaly 13 time (late Eocene-early Oligocene), started the opening of the northern Greenland Sea (Lawver et al., 1990; Eldholm, 1990). Complete continental separation, however, was not achieved until the middle or late Miocene.

The subsidence of the Yermak and the Morris Jesup volcanic features and the opening of the Fram Strait had opened new options for exchange of shallow and deep water masses between the Arctic Ocean and the Nordic Seas. Various models have been suggested for the establishment of a deep-water connection of this gateway (Crane et al., 1982; Eldholm et al., 1987; Lawver et al., 1990; Eldholm, 1990; Kristoffersen, 1990).

The nature and age of the crust underlying the Yermak Plateau have been discussed extensively. Sundvor et al. (1982) suggested the southern part to be of continental origin. Jackson et al. (1984) also ar- gued for a thinned, downfaulted block of continental crust at the southern plateau, with the northern part being created by a hot spot situated at a triple junction. Feden et al. (1979) suggested that the Yermak Plateau and Morris Jesup Rise were created by hot-spot activity between Anomaly 18 and 13 time (middle Eocene to earliest Oligocene). The high heat-flow values observed by Crane et al. (1982) also contradict a partly continental origin of the southwestern plateau, and they argued that oceanic crust not older than $13 \mathrm{Ma}$ underlies the westernmost part of the Yermak Plateau.

The Fram Strait, with a present critical sill depth of $2600 \mathrm{~m}$, is the only deep-water connection between the Arctic Ocean and the global ocean. The initiation of this connection may have taken place as early as Anomaly 13 time, close to the Eocene/Oligocene boundary (Crane et al., 1982; Eldholm et al., 1987; see also reviews by Vogt, 1986a, 1986b). Given the strongly oblique opening of the Fram Strait and the nearness to surrounding land areas (Greenland and Svalbard), it is possible that a true deep Arctic Ocean/Greenland-Norwegian Sea connection became established considerably later than Anomaly 13 time, perhaps as late as Anomaly 6 time.

\section{Southern Gateway}

Few oceanic gateways can compete with the Greenland-Scotland Ridge in having such a profound influence on the present world hydrography (Bott et al., 1983; Wright et al., 1991; Wright and Miller, 1993). Overflow from the north occurs across the Wyville-Thomson Ridge ( $650 \mathrm{~m}$ sill depth), via the Faeroe Bank Channel ( $800 \mathrm{~m}$ sill depth), across the Iceland-Faeroe Ridge (400 m sill depth), and through the Denmark Strait (sill depth about $600 \mathrm{~m}$ ) (Figs. 1, 7). Tracer studies indicate that the overflow waters today originate from waters shallower than $1000-1200 \mathrm{~m}$, probably to a large extent formed by deep convection and water-mass conversion in the Iceland Sea (Peterson and Rooth, 1976; Warren, 1981; Aagaard et al., 1985).

The shallow Greenland-Scotland Ridge (GSR) is an anomalous, partly emerged, volcanic aseismic ridge that transects the North Atlantic Ocean from the East Greenland Shelf to the northern Scottish 


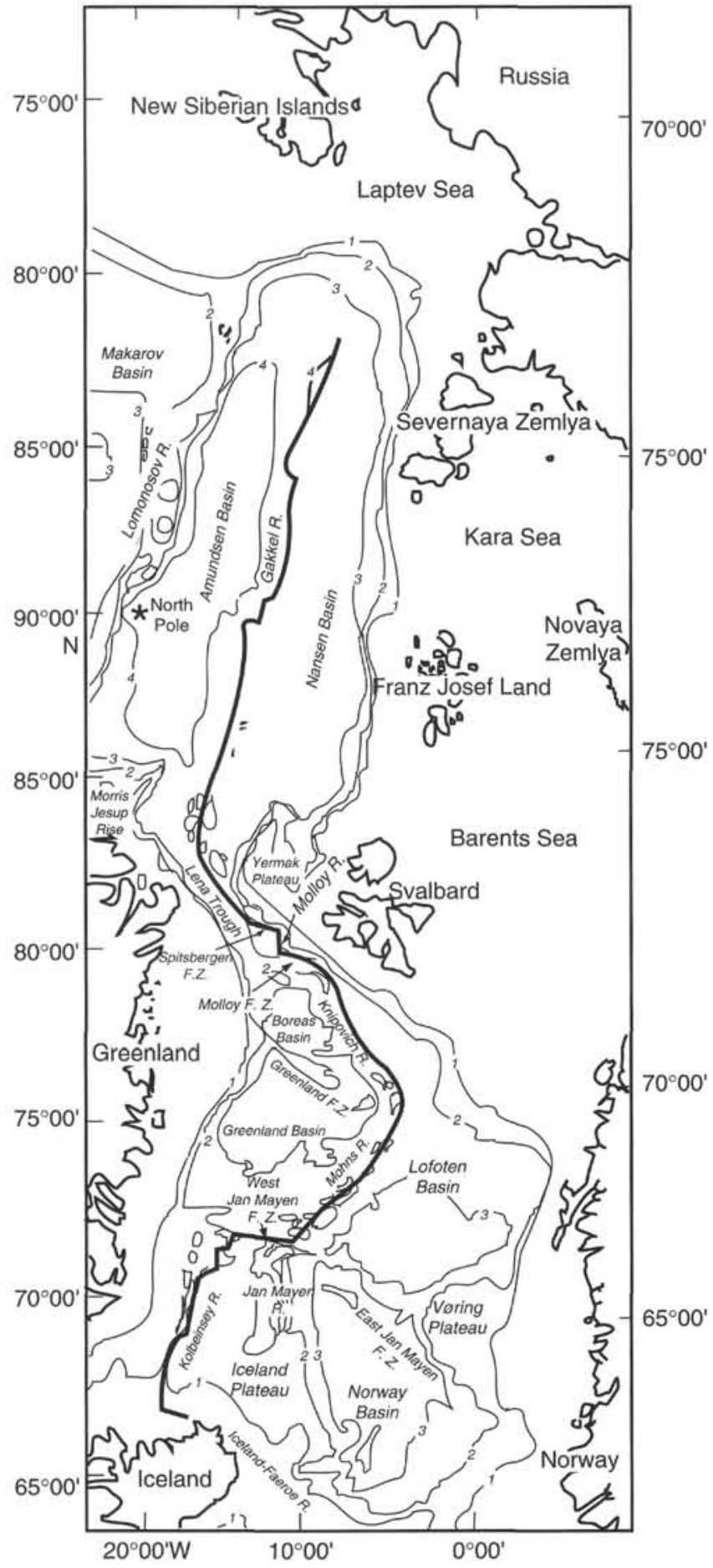

Figure 3. Main physiographic and structural features in the Nordic Seas and eastern Arctic Ocean (from Eldholm et al., 1990). Bathymetry in kilometers.

Shelf. The GSR (Bott et al., 1983) defines the boundary between the main North Atlantic Ocean and the Nordic Seas, and is part of the large volcanic province extending from Baffin Island across Greenland, the Faeroe Islands, to the British Isles. The Denmark Strait between the East Greenland and Iceland shelves has a sill depth of about $600 \mathrm{~m}$ where the two margins almost merge. The East Greenland continental margin broadens to about $250 \mathrm{~km}$ over the ridge, with water depths between 200 and $400 \mathrm{~m}$, but with no well-defined shelf break (Larsen, 1983). The Iceland Shelf toward the Denmark Strait, however, is marked by a clear shelf break with depths to $200 \mathrm{~m}$. The two shelves are divided by the 20 - to 30 -km-wide Denmark Strait Channel. The ridge between Iceland and the Faeroe Islands is nearly 300 $\mathrm{km}$ long and about $200 \mathrm{~km}$ wide. The ridge forms a plateau-like, 400to 600-m-deep area having a smooth crest and separated from the Iceland and Faeroe shelves by short bathymetric scarps (Bott et al., 1983). Between the Faeroe and Scottish shelves lies the 900- to 1000m-deep Faeroe-Shetland Channel system.

The Greenland-Scotland Ridge is a critical gateway for North Atlantic thermohaline circulation. Today most North Atlantic Deep Water (NADW) is derived from cold saline, subthermocline water that spills over this ridge (see below), and these overflows may have been very sensitive to the depth of the sill in the past. The GSR is bisected by Iceland, a major source of volcanic plume activity which has prevented the GSR from following a simple thermal subsidence curve. The buoyant material from the Iceland plume causes large regional topographical anomalies. Vogt $(1971,1983)$ pointed out that long-term fluctuations in mantle plume activity under Iceland could lead to variations in sill depth. Likewise, Wright and Miller (1993) pointed out that episodes of enhanced uplift (and hence shallower sill depth) occurred between 15.5 and $12.5 \mathrm{Ma}$ and between 4.0 and 2.4 $\mathrm{Ma}$. They present evidence suggesting that these were also periods of reduced overflow of waters from the Nordic Seas. Reconstructions of the subsidence history of the ridge system suggest that its eastern parts sank beneath sea level probably sometime during the middle Eocene, and during the early to middle Miocene in the Denmark Strait area. The distribution of shallow-water benthic foraminifers, however, indicates that the Nordic Seas were effectively isolated from any "deep" Atlantic influence until the middle Miocene (Berggren and Schnitker, 1983; Thiede, 1983; Thiede and Eldholm, 1983). We shall be able to test these ideas with the material recovered at Sites $981,982,984,985$, and 907 .

\section{OCEAN CIRCULATION AND WATER-MASS DISTRIBUTION}

The thermohaline circulation of the Atlantic Ocean (the "Great Conveyor") is associated with, and may be largely driven by, dense water formation in the Nordic Seas and other marginal seas. In turn, the thermohaline circulation and its concomitant heat release to the atmosphere is responsible for the relatively (given the latitude) mild climate of western Europe. Many recent studies, both historical (based on paleo-records) and instrumental, as well as modeling results, suggest that modulation of the thermohaline circulation has occurred in the past and is one of the principal factors driving highamplitude climate change in the Northern Hemisphere (Boyle and Keigwin, 1987; Oppo and Fairbanks, 1987; Raymo et al. 1990; GRIP Members, 1993; Weaver and Hughes, 1994; Rahmstorf, 1994; Paillard and Labeyrie, 1994). Recent studies have also shown interdecadal variability in North Atlantic sea-surface temperatures in areas of deep-water-mass formation and transformation (Kushnir, 1994), as well as sensitivity of Greenland Sea sea-ice and freshwater fluxes to El Niño events (Gloersen, 1995).

During the last decade, we have also gained an appreciation of the role of the North Atlantic in the uptake of atmospheric carbon dioxide. Recent studies underscore that the Nordic Seas are quite unique by being a year-round $\mathrm{CO}_{2}$ sink (Takahashi et al., 1993; T. Johannessen, pers. comm., 1995). Furthermore, it is the circulation of this region that appears to maintain the sizable sink of atmospheric $\mathrm{CO}_{2}$ in the North Atlantic Ocean (Watson et al., 1995). Changes in the surface properties of the convective regions would affect the oceanic $\mathrm{CO}_{2}$ sink both by influencing volume transports of carbon and the rates of air-sea exchange of $\mathrm{CO}_{2}$. 


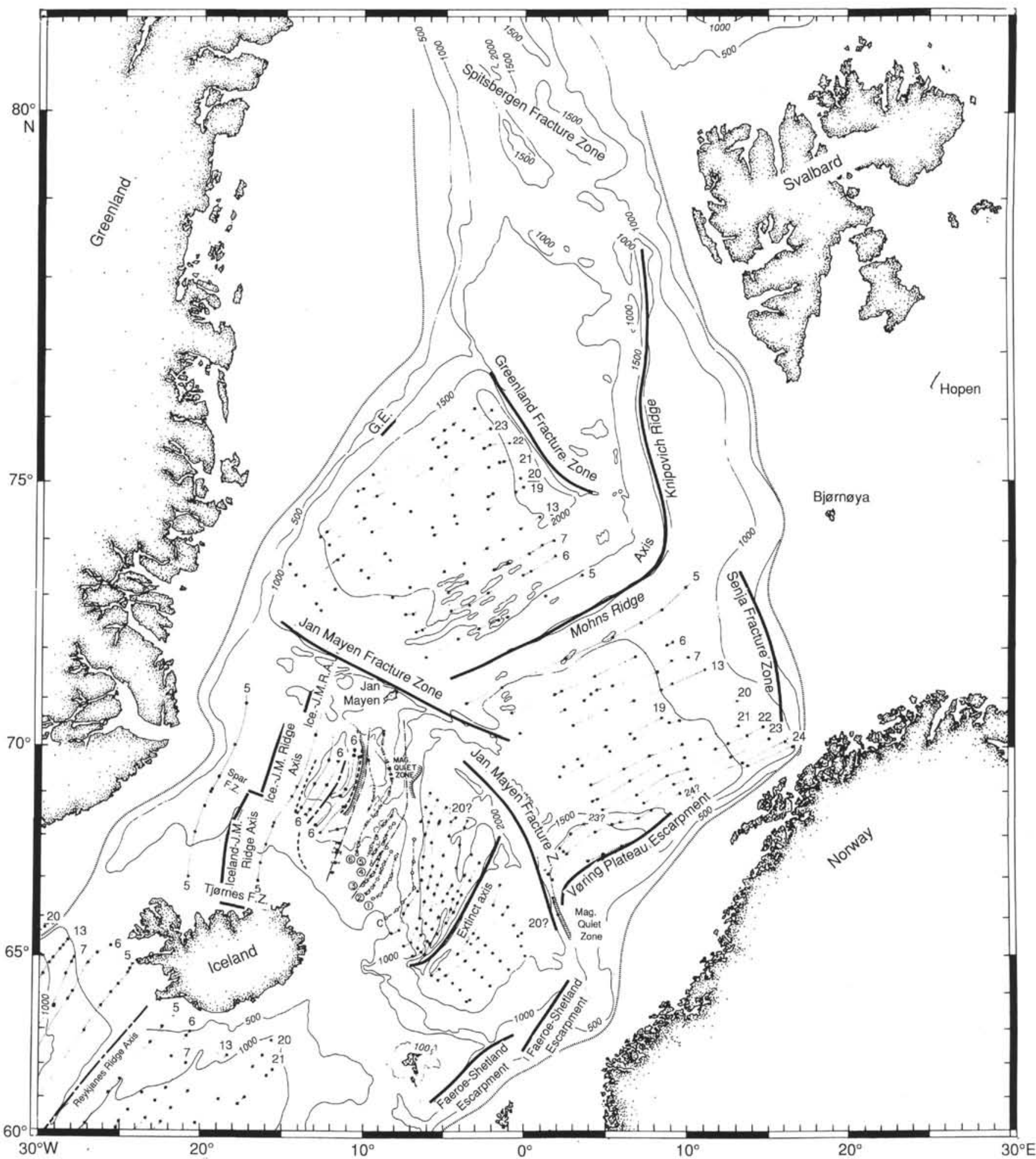

Figure 4. Magnetic lineations in the Norwegian Sea. G.E. = Greenland Escarpment (after Talwani and Eldholm, 1977). Bathymetry in meters.

Some of the main issues in marine research today are, therefore, to understand whether the thermohaline circulation is stable in its present mode of operation, what internal and external forcings are required to maintain or change it, and what impacts such changes might have. Because of limitations of instrumental records (e.g., the reduced time span and, hence, less variation in boundary conditions and forcing variability), unraveling the natural variability of the thermohaline circulation and its response to different forcing scenarios will depend on paleoceanographic reconstructions based on studies of longer sediment records.

\section{Nordic Seas and Arctic Ocean (The "Arctic Mediterranean")}

The Nordic Seas act as a passageway for water-mass exchange between the North Atlantic and the Arctic, but are also an area of major 


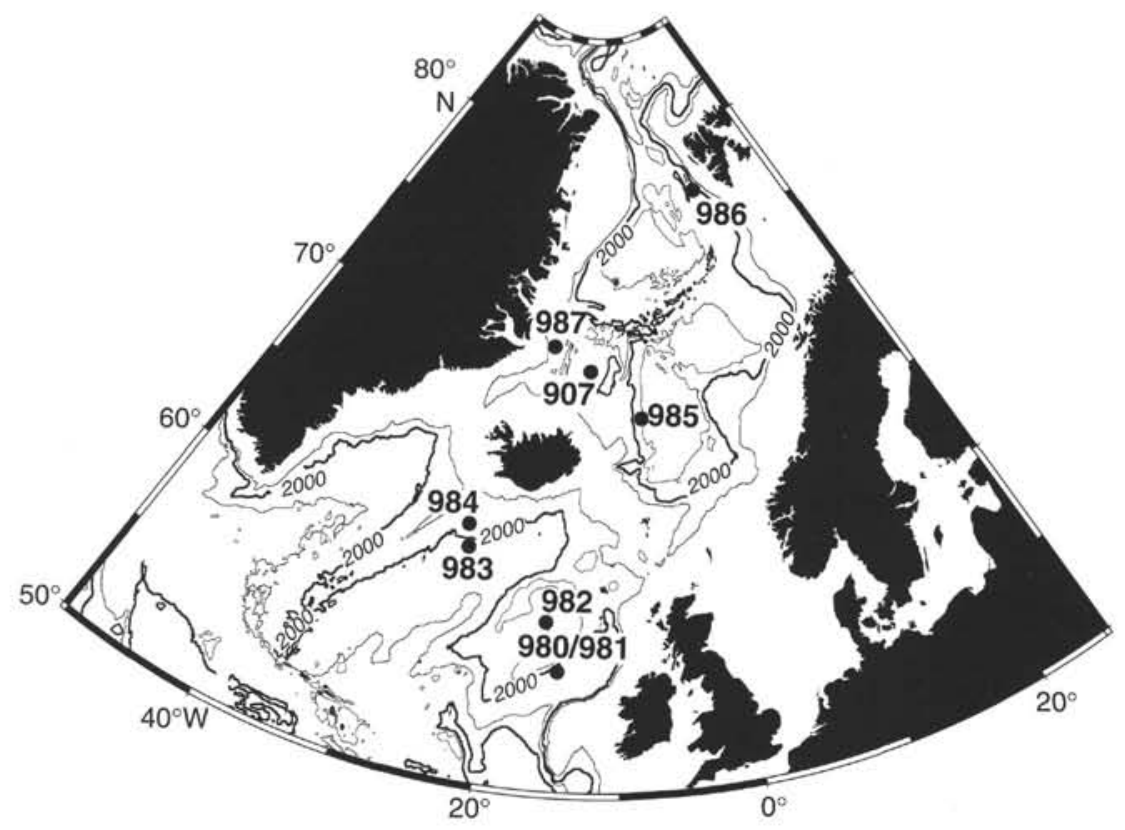

Figure 5. Map view of sites drilled during Leg 162.

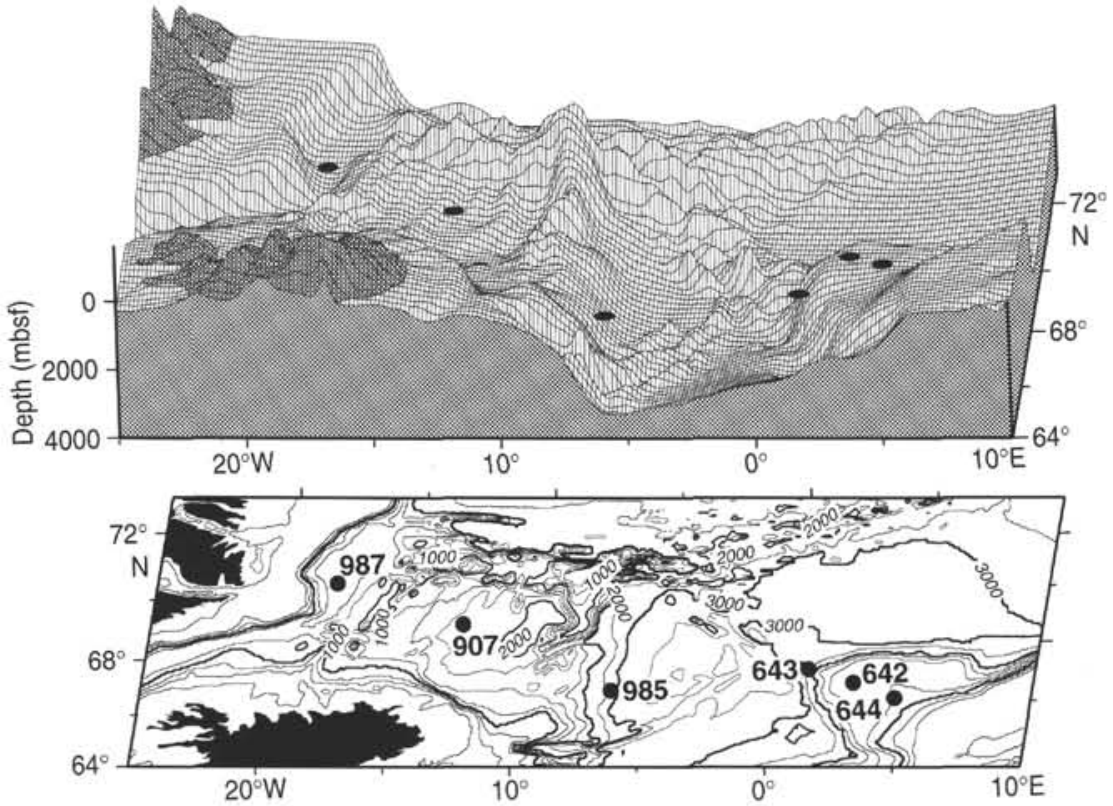

Figure 6. Bathymetry of the Nordic Seas paleoenvironmental transect, showing location of drill sites from Legs 104, 151, and 162. Bathymetric data (in meters) from ETOPO5. water-mass conversion and formation. The main surface circulation is characterized by inflow of warm, saline Atlantic water by the Norwegian Atlantic Current in the east and outflow of cold, low-salinity water and sea ice via the East Greenland Current in the west (Fig. 7). The annual mean heat flux created by the cooling of inflowing waters in the Nordic Seas amounts to $242 \times 10^{12} \mathrm{~W}$ (Simonsen and Haugan, in press), and the resulting densification and transformation of water masses drive the thermohaline overturning (convection) in the Arctic Mediterranean. Saline water of Atlantic origin mixes with low-salinity, cold polar water masses to form Arctic water masses in the convective gyres of the Greenland and Iceland Seas. Given sufficient cooling, these waters are saline enough to convect. The loss of salin- ity due to mixing with fresh polar water is compensated for by the increased compressibility of cold water, allowing surface waters to become denser than underlying warmer and saltier water masses.

The heat import to the Nordic Seas limits the sea-ice extent, which at present has a strong annual variability. The permanent ice cover in the Arctic Ocean, on the other hand, is maintained by the buoyancy of the freshwater layer that originates from freshwater influx from the Amerasian rivers and influx of low-salinity surface waters via the Bering Strait. Atlantic water masses enter the Arctic Ocean via the Fram Strait, crossing the Yermak Plateau, and also via the Barents Sea. These warmer waters sink beneath the permanent halocline of the Arctic Ocean, circulate around the basin, and exit out of the Arctic 
Ocean through the Fram Strait as a noticeable subsurface temperature maximum. Any change in the density structure of the surface layer could result in reduced sea-ice cover and, therefore, a potential for this subsurface heat to be released at the surface. This is a potential mechanism for high-amplitude climate change (see schematic in Figs. 8, 9).

Convection at high latitudes has long been recognized as the prime mechanism for the ventilation of the deeper layers of the world ocean. The two main sources are the Weddell Sea, producing Antarctic Bottom Water (AABW), and the North Atlantic, where North Atlantic Deep Water (NADW) is supplied by overflows across the Greenland-Scotland Ridge through the Denmark Strait and FaeroeShetland Channel (Figs. 1, 7), as well as by convection in the Labrador Sea. The North Atlantic thermohaline circulation is robust and vigorous, and involves the transport of large quantities of deep water into the Southern Hemisphere. It differs greatly from the North Pacific circulation, which is characterized by a thin layer of ventilated waters at the surface.

The North Atlantic thermohaline circulation has been likened to a thermal flywheel that provides temporary storage of heat during periods of climate change and affects the rate of change of global surface temperatures over time scales from years to centuries. NADW ventilates more than half the volume of the deep world ocean. This volume and the rate of its ventilation determine the capacity of the oceans to retard and weaken atmospherically and radiationally imposed climate changes. It is therefore necessary to properly document, upstream and downstream of the GSR overflows, the variability of the sources of NADW to understand the history, strength, and stability of the global thermohaline circulation.

The dense water of the GSR overflows, which feed the North Atlantic deep circulation, is formed in the Arctic Ocean and in the Greenland and Iceland Seas (Figs. 8, 9). The Greenland Sea has been considered the most important source of deep and bottom water in the Arctic Mediterranean, and it is one of the few areas of the world ocean where open-ocean convection can reach more than $3000 \mathrm{~m}$ depth. Great efforts have been directed to the study of the nature and strength of this convection, and several mechanisms have been proposed: a combination of wind-driven, cyclonic circulation and cooling at the sea surface (Nansen, 1906), upwelling and subsequent cooling at the ice edge (Häkkinen, 1987; Guest and Davidson, 1991), subsurface double-diffusive convection (Carmack and Aagaard, 1973), and haline convection caused by brine release during ice formation (Rudels, 1990).

The Arctic shelves are a second source for the deep and bottom water of the Arctic Mediterranean (Rudels and Quadfasel, 1991). Here, brine released during ice formation accumulates at the bottom of the shelves, continuously increasing the salinity of the shelf bottom water during the winter. Eventually the dense shelf bottom waters escape across the shelf break and sink as entraining boundary plumes into the basins. The water-mass characteristic of the end product is largely determined by the entrainment of the ambient layer of warmer Atlantic water. This gives the present deep waters of the Arctic Ocean a relatively warm, saline signature. A second factor, also related to the stratification of the water column, and one that affects the strength of the convection, is the amount of ice formation needed to make the mixed layer dense enough to convect. If the upper layer is of too low salinity, the ice cover will become too thick and the atmospheric heat loss so reduced that no deep convection can occur.

Deep intermittent convection has been observed in the Greenland Sea (Rudels et al., 1989). However, no convection event reaching to the bottom has been documented recently, and the deep-water formation in the Greenland Sea appears to have been reduced over the last 25 years (Schlosser et al., 1991). When the deep convection in the Greenland Sea becomes weaker and reaches down to only about 1000 $\mathrm{m}$, it remains above the deep temperature maximum of the Greenland Sea Deep Water (GSDW), which is derived from an influx of Arctic Intermediate Water (AIW) and deep water originating from the Canadian Basin of the Arctic Ocean. As the influx of Arctic Ocean deep waters through Fram Strait has continued in the absence of deep convection in the Greenland Sea, GSDW has become markedly warmer and more saline over the past $10-15$ years. The deeper basins are not

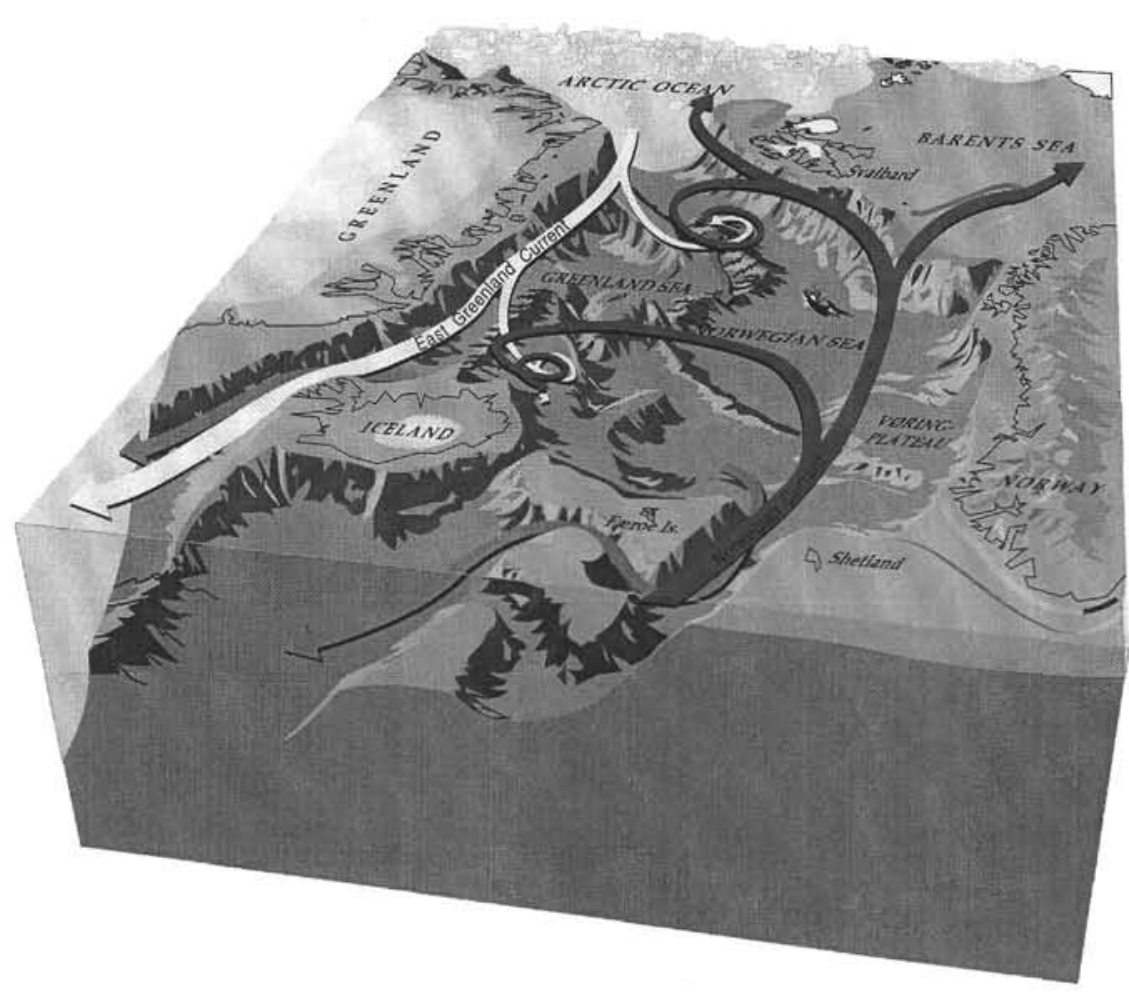

Figure 7. Three-dimensional schematic map of the Nordic Seas with main surface currents and sites of modern deep-water formation and overflows marked by arrows (computer graphics by $\mathrm{M}$. Adachi, University of Bergen). 


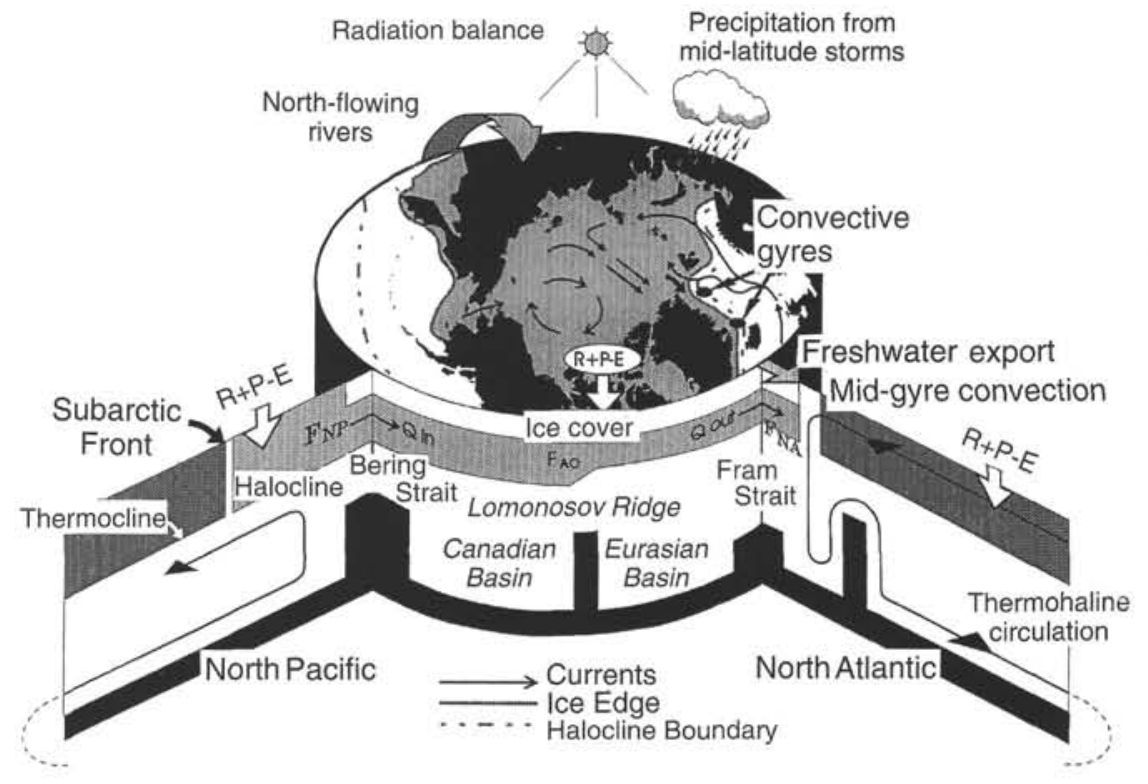

Figure 8. Schematic Arctic Ocean/Nordic Seas climate connections. In the horizontal plane the extent of sea ice in winter is shown by the shaded region, and the mean surface circulation by arrows. Sections from the North Pacific and the North Atlantic extend through the Bering and Fram Straits. The Subarctic Front separates the salt-stratified upper waters of the Arctic and subarctic oceans from the temperature stratified upper waters of the subtropical oceans. The components of the freshwater balance include runoff $(\mathrm{R})$, precipitation $(\mathrm{P})$, evaporation (E), storage in the upper North Pacific $\left(\mathrm{F}_{\mathrm{NP}}\right)$, Arctic Ocean $\left(\mathrm{F}_{\mathrm{AO}}\right)$, and the North Atlantic $\left(\mathrm{F}_{\mathrm{NA}}\right)$, and the horizontal freshwater fluxes ("Q in" and "Q out"). Solid ovals indicate the present sites of convection in the Greenland and Iceland Seas. (From Aagaard and Carmack, 1994).

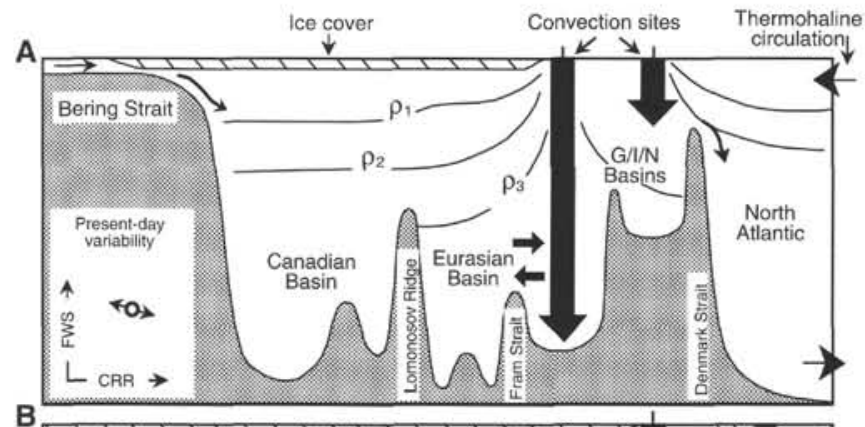

B

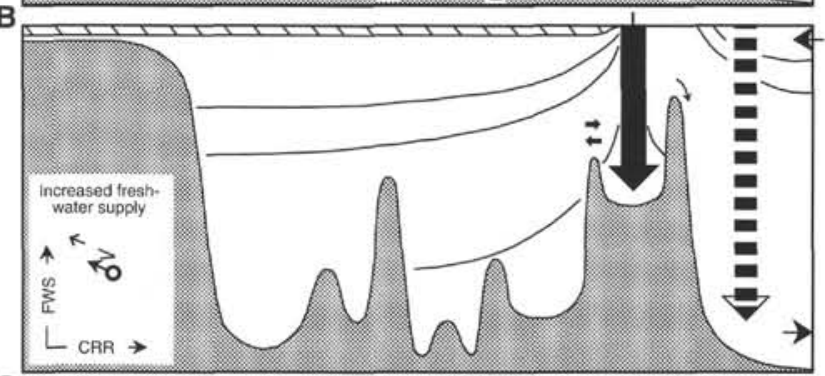

C

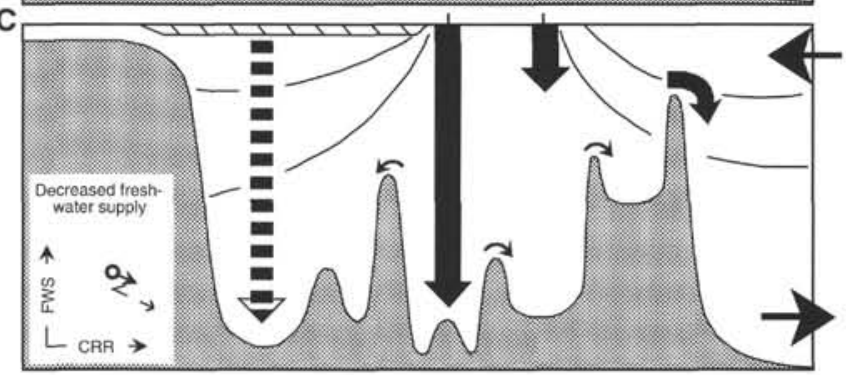

Figure 9. Hypothesized dependence of the convective renewal rate (CRR) on freshwater supply (FWS) under (A) present conditions, (B) increased freshwater supply, and (C) decreased supply. The dashed arrows indicate possible transitions to different circulation modes. (From Aagaard and Carmack, 1994). $\mathrm{G} / \mathrm{I} / \mathrm{N}=$ Greenland/Iceland/Norway. being ventilated by the convection in the Greenland Sea but only by boundary convection from the shelves of the Arctic Ocean, if at all.

This AIW in turn supplies the water to the shallow GSR overflows and, thus, the total production of NADW should not be affected, although its characteristics may vary on decadal time scales. The temperature, salinity, nutrients, and dissolved gases in AIW compared to GSDW differ markedly. Also, the formation areas (and residence times) of AIW and GSDW are different. Open-ocean convection to intermediate depths also takes place in the Iceland Sea. The overflow waters exiting across the GSR are at present a combination of waters that convected to intermediate depths in the Iceland and Greenland Seas and waters that advected and mixed in from the Arctic and from below, with a short residence time. Cessation of ventilation of the deep waters in the Arctic Mediterranean would lead to a dramatic shallowing of the lysocline in this ocean due to the ridges isolating the deep basins from communication with the global ocean. It is possible, however, that ventilated overflows would still continue at intermediate depths. Neogene sections from previous ODP drilling in the Nordic Seas document quite extensive noncarbonaceous phases and periods of extensive carbonate dissolution prior to the last $1 \mathrm{Ma}$ (Eldholm, Thiede, Taylor, et al., 1987; Myhre, Thiede, Firth, et al., 1995). The continuous records obtained during Leg 162 from both sides of the Southern Gateway will enable us to assess changes in ventilation by monitoring the temporal evolution of the Nordic Seas lysocline, and by sampling and determining the geochemical characteristics of the overflow waters.

Thus, outflow from the Arctic Ocean conditions the convection cells in the Greenland and Iceland Seas both at the surface and at depth. At the surface this happens as a result of the freshwater export by low-salinity waters and sea ice, which will reduce surface salinity and density when melting in the Greenland and Iceland Seas. Such a stabilization of surface water apparently happened in recent decades (the "great salinity anomaly"; Dickson et al. 1988), and is used in many conceptual models of causes for millennial- to decadal-scale variability in climates during the late Pleistocene (e.g., Broecker et al., 1985). At depth, the outflow of warmer intermediate waters in the subsurface temperature maximum provides heat, which also reduces convection. Therefore, changes in sea-ice production, as well as changing export of sea ice and water masses from the Arctic Ocean, have the potential to impact Northern Hemisphere climates. The paleoclimatic transect of Legs 104, 151, and 162 sites between Greenland and Norway is designed to capture such changes, and the drift 
sites in the North Atlantic will provide comparable records from more southern sites and also enable a detailed understanding of how the deep overflows may vary in response to the changing inflow and outflow of water between the Atlantic and the Arctic Ocean/Nordic Seas.

\section{North Atlantic Circulation}

NADW forms from a mixture of deep and intermediate waters originating from the Nordic Seas, the Labrador Sea, and entrainment of subthermocline water in the North Atlantic (including Mediterranean Outflow Water). There is no reason to expect the relative contribution from these different source areas to remain constant on any time scale, and a major objective of this leg is to assess the relative flux of different NADW components through time through their geochemical and sedimentological signatures. In particular, the sediment drifts, on which our drilling south of Iceland was concentrated, have formed by bottom currents derived from Greenland-Scotland Ridge overflows. These waters are usually referred to as Norwegian Sea Overflow Water (NSOW) but can be subdivided into smaller water masses based on their temperature and salinity characteristics and on the location on the ridge where they overflow.

The densest and volumetrically most important overflow is Denmark Strait Overflow Water (DSOW), which enters the Irminger Basin between Iceland and Greenland (Fig. 7). This water has a potential temperature of $1^{\circ}-2^{\circ} \mathrm{C}$ and a salinity of 34.9 (Peterson and Rooth, 1976; Swift, 1980; Wold, 1994). Farther to the east, NSOW flows across the ridge between Iceland and the Faeroe Islands and enters into the Iceland Basin east of the Reykjanes Ridge. This water has been named Iceland-Scotland Overflow Water (ISOW) by McCave and Tucholke (1986) and has a potential temperature of $5^{\circ} \mathrm{C}$ and a salinity of 35.1 (Wold, 1994). An additional flux of NSOW to the Iceland Basin travels through the Faeroe Bank Channel after spilling over the Scotland-Faeroe section of the ridge (Figs. 1, 6). This water has a potential temperature of $3^{\circ} \mathrm{C}$ and salinity of 35.1 .

Lastly, some of the water that flows over the Faeroe-Shetland Channel is deflected southward over the Wyville-Thomson Ridge (Figs. 1, 2). This water enters the Rockall Trough, where it flows southward along the western margin of this trough and builds up the Feni Drift. This water mass, Wyville-Thomson Ridge Overflow (WTRO; potential temperature $=6^{\circ} \mathrm{C}$; salinity $=35.1$ ), is directed around the southern margin of the Rockall-Hattan Bank by the Coriolis force and eventually flows northward along the eastern margin of the Iceland Basin (Fig. 1). At the north end of this basin, this water mass joins ISOW before it is steered southward along the western margin of the Iceland Basin. Eventually this water, including a large amount of entrained water, enters the western North Atlantic by flowing over deeper sections of the Reykjanes Ridge and through the Charlie-Gibbs Fracture Zone. The physical characteristics and estimated fluxes of all the above water masses are given in a table in Wold (1994).

A major component of the water entrained by NSOW after entering the North Atlantic is Lower Deep Water (LDW, as defined by McCartney, 1992). This water mass lies under NSOW and is formed by NADW and AABW, which enter the eastern Atlantic Basin through low-latitude fracture zones. This water moves northward as an eastern boundary current, eventually contributing to a cyclonic deep recirculation gyre south of the Rockall Plateau (McCartney, 1992).

\section{Sediment Drifts}

In addition to looking at geochemical indicators of water-mass circulation, we shall also examine the Neogene history of sediment drifts in the North Atlantic. The presence and evolution of sediment drifts are intimately linked with the deep-water circulation patterns in this region, and the drifts are presently being sculpted by the NSOW water overflowing the Wyville-Thomson Ridge, Iceland Ridge, and Denmark Strait (Jones et al., 1970; Heinrich, 1988; Miller and Tucholke, 1983; Wold, 1994). Three major drifts were drilled on this leg: the Feni Drift on the flank of the Rockall Trench, and the Gardar and Bjorn Drifts on the eastern flank of the Reykjanes Ridge (Figs. 1, $10)$.

Sediment drifts are formed by bottom-water currents that erode deep-sea sediment in one location and deposit it in another. The path of the deep currents is controlled by existing topography and the Co-

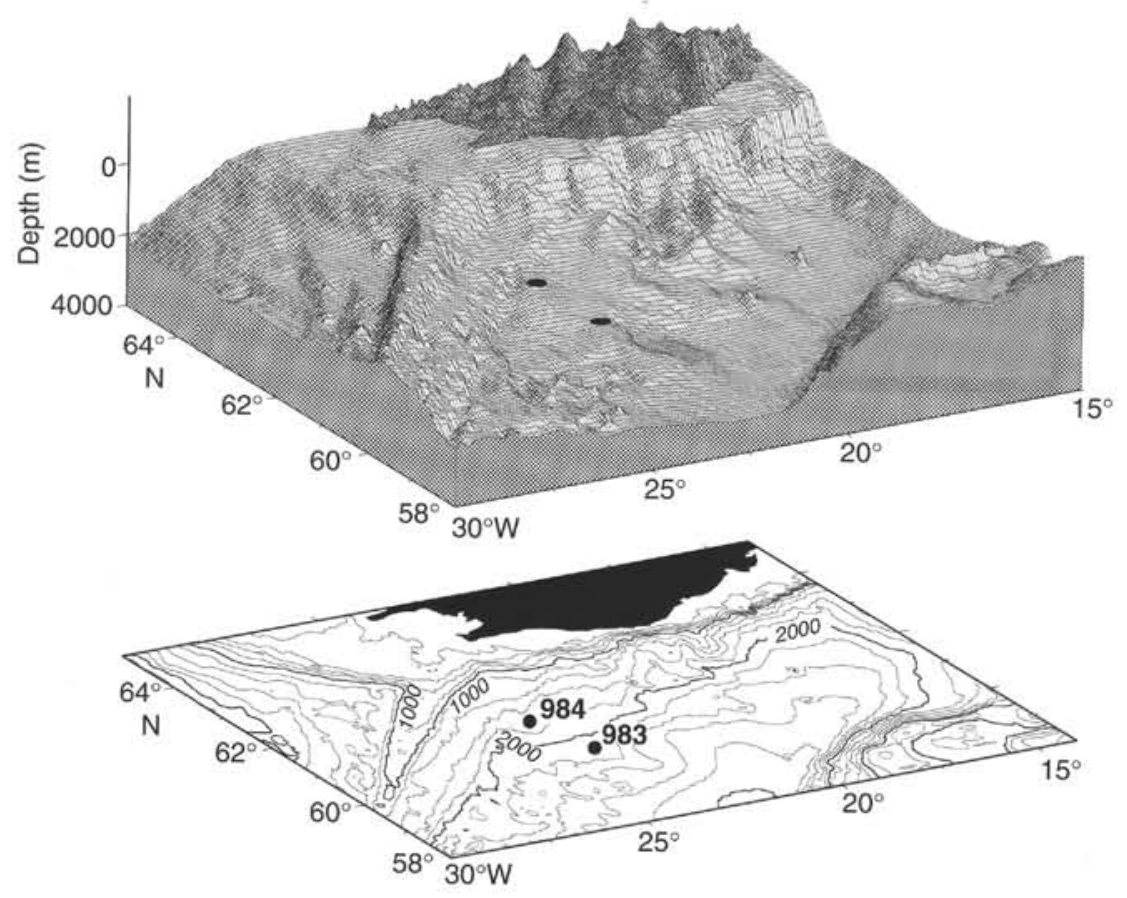

Figure 10. Detailed bathymetry of the Gardar and Bjorn Drift region showing locations of Sites 983 and 984. Bathymetric data (in meters) from ETOPO5. 
riolis effect (Fig. 1). Where fine-grained sediment settles out of the current nepheloid layer, large drifts build up that typically have sedimentation rates in excess of $10 \mathrm{~cm} / \mathrm{k}$.y. due to the excess fine fraction. At the Feni Drift, this fine-grained material is predominantly pelagic in origin. On the Bjorn and Gardar Drifts, much of the suspended material is terrigenous silts derived from Iceland.

As documented by Kidd and Hill (1987) and Wold (1994), and references therein), the Feni Drift began forming near the EoceneOligocene boundary. However, the source of the current that started building the drift is uncertain. Possible candidates include WyvilleThomson Ridge Overflow water, AABW currents from the south, remnant Tethyan outflow, or lastly, dense saline water formed on the nearby Rockall Plateau.

By contrast with the Feni Drift, the Gardar and Bjorn Drifts are believed to have begun forming in the late early to middle Miocene (Wold, 1994). Henrich et al. (1989) and Locker and Martini (1989) present evidence for cooling in the Norwegian Sea at this time. This suggests that the initiation of dense water flows over the GSR may have been responsible for the initiation of drift sedimentation just downstream (Wold, 1994). Geochemical evidence for a change in the intermediate-water regime just south of the GSR may be apparent in the sedimentary record from Site 982 , which extends back to the early Miocene.

Likewise, we can evaluate ideas about the interactions between drift sedimentation, ridge elevation, and deep-water overflows in the context of the Pliocene-Pleistocene record. Wright and Miller (1993) link increased elevation of the GSR to decreased thermohaline overflow and predict weak NSOW formation between 4.0 and 2.4 Ma. Wold (1994) further proposes that this episode of uplift and weaker NSOW correlated to a period of more rapid drift sedimentation along the Bjorn and Gardar Drifts (as less fine-grained material is kept in suspension). However, one could also argue that stronger NSOW production could intensify erosion and transport of fine-grained material to drift locations. Geochemical studies of the middle Pliocene suggest that NADW was quite strong at this time (e.g., Raymo et al., 1992).

For many excellent articles on sediment drifts of the North Atlantic the reader is referred to two special issues of the journal Paleoceanography (December 1994 and June 1995), as well as to the Scientific Results of DSDP Leg 94 (Ruddiman, Kidd, Thomas, et al., 1987).

\section{CLIMATE EVOLUTION OF THE NORTH ATLANTIC-ARCTIC REGION}

\section{Cenozoic History}

The gateways in the north (Fram Strait) and south (GreenlandScotland Ridge) are among the most important submarine topographic constrictions to global oceanic circulation. Opening of the Fram Strait and subsidence of the Greenland-Scotland Ridge below critical levels are necessary conditions for deep-water exchange between the Arctic Ocean, Nordic Seas, and Atlantic Ocean. The history of these gateways is thus a key component in understanding the long-term evolution of both Northern Hemisphere climate and global thermohaline circulation, and a major objective of this leg is to unravel the long-term history of surface-, intermediate-, and deep-water chemistry and the exchange of water masses across these gateways.

Basic questions as to why and when NADW production was initiated, and how and why the chemical and physical signature of this major water mass has varied, remain to a large degree unanswered. A number of studies have suggested that northern-component deep water began forming around 12.5 Ma (Woodruff and Savin, 1989; Wright et al., 1992). However, biosilica-rich deposition suggests an anti-estuarine circulation in the Nordic Seas until about $7 \mathrm{Ma}$ (Myhre,
Thiede, Firth, et al., 1995) or at least a lack of convection to basin depths. The late Miocene also saw the beginning of a major growth phase for sediment drifts south of the Greenland-Scotland Ridge (Wold, 1994). Note, however, that these drifts were present earlier and hence cannot exclude earlier deep-water exchange over the GSR. Geochemical analysis of carbonate at Site 982 (NAMD-1) will address this question, as well as document North Atlantic water-mass circulation prior to the existence of NADW.

Overall, characterization of surface and deep waters in the main source regions (Sites 907, 985, and 987) and directly south of the ridge (Sites 980, 981, 982, 983, and 984) will greatly improve our understanding of world ocean hydrography, global energy and $\mathrm{CO}_{2}$ budgets, and North Atlantic patterns of sedimentation and erosion. Related objectives are understanding the long-term history of biogenic fluxes in the region, in particular the bathymetric variability of the carbonate compensation depth (CCD) and lysocline and the spatial and temporal history of silica preservation and production.

The Neogene evolution of sea-ice cover in this region will also be examined. The present Arctic climate is strongly influenced by its sea-ice cover, which greatly increases the regional albedo and reduces heat and gas exchange with the atmosphere. Very little is known about how this ice cover first developed and subsequently varied. It has been proposed that the Arctic Ocean has been permanently icecovered since the late Miocene (Clark, 1982). Other studies conclude that perennial sea-ice cover developed in the Matuyama Chron ( 0.78 to $2.58 \mathrm{Ma}$ ) or at the Brunhes/Matuyama chron boundary (Herman and Hopkins, 1980; Carter et al., 1986; Repenning et al., 1987). Although ice precludes drilling within the central Arctic, drilling by the JOIDES Resolution along the present ice margins will provide sediments to better constrain the history of sea-ice extent.

In addition to investigating the evolution of thermohaline circulation, the Leg 162 sites will also elucidate the history of Northern Hemisphere glaciation in the circum-Arctic and North Atlantic region. Results from DSDP Leg 94 and ODP Leg 104 demonstrated that the onset of significant Northern Hemisphere glaciation (defined by a noticeable increase in the amount of ice-rafted sediments in the open North Atlantic and the eastern Nordic Seas) occurred in the upper part of the Gauss Chron at approximately $2.75 \mathrm{Ma}$ (Raymo et al., 1989; Jansen and Sjøholm, 1991). In the North Atlantic this took place in oxygen isotope Stage G8 (previously Stage 112 of Raymo et al., 1989). The later, and seemingly more abrupt, onset of glaciation inferred from DSDP Site 552 (Shackleton et al., 1984) was an artifact of an 150-k.y. missing interval between 2.6 and $2.8 \mathrm{Ma}$ in that hole (see Raymo et al., 1989). Between 2.75 and $2.50 \mathrm{Ma}$, glacial episodes become progressively more severe, as reflected in both progressively heavier $\delta^{18} \mathrm{O}$ values and more southward appearance of ice-rafted debris (IRD) (Raymo, 1994). At Sites $609\left(50^{\circ} \mathrm{N}, 24^{\circ} \mathrm{W}\right)$ and 610 $\left(53^{\circ} \mathrm{N}, 19^{\circ} \mathrm{W}\right)$ noticeable IRD is first observed at $2.75 \mathrm{Ma}$, while at Site $607\left(41^{\circ} \mathrm{N}, 23^{\circ} \mathrm{W}\right)$ IRD is not observed until about $2.63 \mathrm{Ma}$ (Raymo et al., 1989; H. Kleiven, pers. comm., 1995). Finally, at 2.5 $\mathrm{Ma}$, a pronounced increase in IRD delivery is observed throughout the North Atlantic Ocean extending southward beyond $40^{\circ} \mathrm{N}$. This event is associated with oxygen isotope stage 100, which is approximately $0.5 \%$ heavier than any prior cooling event. This event clearly reflects a large increase in ice volume somewhere in the circum-Arctic region.

Results from ODP Leg 104 showed that the Fennoscandian Ice Sheet was present back to $2.75 \mathrm{Ma}$ (Jansen and Sjøholm, 1991) and, therefore, it is possible that the IRD observed in the open North Atlantic came from this region. The presence of IRD at 2.9 Ma on the Iceland Plateau suggests that Greenland ice sheets existed earlier (Jansen and Sjøholm, 1991; Fronval and Jansen, in press). Likewise, sporadic earlier occurrences of minor quantities of IRD in various Nordic Seas and North Atlantic drill sites near Greenland, including Legs 151 and 152, indicate a still-earlier onset of glaciation around 
the Nordic Seas. These results show a general cooling of the Norwegian Sea region during the last $12 \mathrm{Ma}$, with major cooling events around 11.0 and 6.4 Ma (Jansen and Sjøholm, 1991; Fronval and Jansen, in press). At the Vøring Plateau, the oldest pulses of glacial IRD date to around $12 \mathrm{Ma}$, indicating that glaciers for the first time reach sea level at this time (Fronval and Jansen, in press). The records of ice-borne deposits document a significant intensification of glaciation around 7.0 and $6.0 \mathrm{Ma}$, which reflect the onset of middle-sized glaciation in the Northern Hemisphere (Larsen et al., 1994; Fronval and Jansen, in press).

IRD and opal data from ODP Leg 105 (Site 646) suggest discontinuous sea-ice cover has existed in the Labrador Sea to the south of Greenland since the middle/late Miocene (Wolf and Thiede, 1991). Terrestrial data indicate significant cooling on Iceland at about $10 \mathrm{Ma}$ (Mudie and Helgason, 1983) and glaciation in elevated areas of Iceland in the latest Miocene and the Pliocene (Einarsson and Albertsson, 1988). However, both the location of the earlier ice sheets and the kind of glaciation remain uncertain. Were these mountain glaciers that reached the sea, or small continental ice sheets? Were they located on Greenland, on Svalbard, or over the Barents Sea? What distinguished the climatic responses in the Arctic parts of this area (Greenland, Svalbard, and Arctic Ocean fringes) from those of the subarctic North European areas? Did the cooling and glacial inception of the high Arctic and Greenland take place at an earlier or later stage than in the subarctic? Unfortunately, drilling during Leg 151 did not penetrate the glacial package at the Fram Strait/Yermak Plateau sites selected for this purpose. It is thus a primary drilling objective to obtain sediments from sites adjoining each of these regions to assess their glacial histories individually.

As discussed above, a major threshold of the climate system was passed with the inception of widespread continental glaciation in the late Pliocene. After this time, large ice sheets, approximately onehalf to two-thirds the size of late Pleistocene ice sheets, grew and decayed primarily at the 41-k.y. periodicity of orbital obliquity (Ruddiman, Kidd, Thomas, et al., 1987; Ruddiman and Raymo, 1988; Raymo et al., 1989; Raymo and Ruddiman, 1992). At 1 Ma, a major shift in the mode of ice-sheet variation is observed as the average icesheet size increases significantly and the periodicity of ice-volume variation increases to approximately $100,000 \mathrm{yr}$ (Pisias and Moore, 1981; Ruddiman et al., 1986; Ruddiman et al., 1989; Raymo, 1992; Berger and Jansen, 1994; Fronval and Jansen, in press). In addition to a shift toward more extensive glaciations of longer duration, warmer interglacials with possibly less continental ice (lighter $\delta^{18} \mathrm{O}$ ) are observed in the late Pleistocene record. These extreme interglacials, including stages $1,5,7,9$, and 11 , are associated with enhanced influx of Atlantic waters to the Nordic Seas as well as with more ventilated deep waters in this region (Spiegler, 1989; Henrich, 1989; Berger and Jansen, 1994; Fronval and Jansen, in press) as inferred from a transition from carbonate-free to carbonate-bearing sediments in this region. How this transition relates to the regional climate and oceanographic history is poorly understood. Terrestrial evidence indicates forested areas in the Arctic fringes, far north of the present forest/tundra boundary, until about $2 \mathrm{Ma}$ (Carter et al., 1986; Nelson and Carter, 1985; Funder et al., 1985; Repenning et al., 1987). The chronology from these land sites is poorly constrained, however, and no continuous records from land sites document the transition into a cold Arctic climate.

\section{Milankovitch Variability}

Over the past few decades, it has become clear that much of the natural variability in the Earth's environment on time scales less than a million years originates in the geometry of the Earth-Sun orbital system. It is likely that the sensitivity of the Earth's climate to orbital forcing increased during the late Cenozoic because of the increased extent of snow and ice, with particularly high sensitivity in the last million years. Obtaining records that document the development of these climatically sensitive latitudes is critical for elucidating how, why, and when enhanced sensitivity evolved and for improving our understanding of the mechanisms by which orbital insolation variations have forced Cenozoic climatic change (e.g., Imbrie et al., 1992, 1993). In particular, glacial-interglacial changes in deep-water formation in the Nordic Seas are implicated as the key driving force in conceptual models of atmospheric $\mathrm{CO}_{2}$ variations and global climate change (Boyle, 1988; Imbrie et al., 1992). Unfortunately, the lack of high-quality records from the highest northern latitudes has precluded comprehensive evaluation of these hypotheses.

Leg 162 records will improve our understanding of deep-water evolution north of the Southern Gateway by providing spatial and vertical transects that constrain the development of physical/chemical gradients in deep water and their response on Milankovitch time scales. Drilling at Sites $980-984$ south of the gateway will provide sorely needed shallow and intermediate water depth end-members for Atlantic-scale studies of thermohaline circulation (e.g., Raymo et al., 1990, 1992; deMenocal et al., 1993; Oppo et al., 1995). We will reconstruct water-mass behavior in the North Atlantic on glacial-interglacial time scales of the Pliocene/Pleistocene, with special emphasis on the formation of Glacial North Atlantic Intermediate Water and its links to surface-water conditions.

\section{Millennial-Scale Climate Variability}

Sites on the North Atlantic sediment drifts (Sites 980, 981, 983, and 984 [FENI-1, -2, GARDAR-1, and BJORN-1]) will allow us to address several questions relating to climatic variability on a range of time scales. From recent investigations on high-sedimentation-rate marine cores, it is evident that rapid oscillations like those observed in temperature, snow accumulation rates, and dustiness in Greenland ice cores (Dansgaard-Oeschger, events) also exist in the marine record (Heinrich, 1988; Bond et al., 1992, 1993; Broecker, 1994). They can be recorded as changes in surface fauna (sea-surface temperature), carbonate content, sediment color, and deep-ocean chemistry. The transitions between cold and warm epochs in ice cores are abrupt: $\sim 6^{\circ} \mathrm{C}$ warmings occurred in as little as $20 \mathrm{yr}$ and four-fold drops in dust content in $<20$ yr. Broecker (1994) reviews possible causes for these oscillations and the linkages between deep-sea sedimentation and ice-core records. One possibility is that millennialscale climate variations in ice cores are related to the strength of the thermohaline "conveyor belt." In addition to examining this hypothesis, we will use the long, high-sedimentation-rate cores to determine whether these oscillations characterized the marine record during earlier, warmer climatic regimes of the past $3 \mathrm{~m} . \mathrm{y}$.

Also found in the marine record are events with longer characteristic repeat times $(\sim 10,000 \mathrm{yr})$, which may be related to surges of the eastern Laurentian Ice Sheet (Bond et al., 1993; Broecker, 1994). However, Heinrich-layer-type sedimentation patterns, originating from variability of the North European Ice Sheet, indicate that ice sheets on both sides of the North Atlantic varied in a coupled, coherent manner at millennial time scales in the late Pleistocene (Bond and Lotti, 1995; Fronval et al., 1995). Similarly, studies at Sites 912, 986, and 987 will provide information on the suborbital-scale variability of the other main Northern Hemisphere ice sheets. Determining the geographic distribution of these Heinrich events, their long-term character, and the timing of their first occurrence is a main objective of drilling on the Feni, Gardar, and Bjorn Drifts. For instance, are they restricted to the "100-k.y. world" of the Brunhes Chron, characterized by the largest continental ice sheets? By studying sedimentation patterns, surface-water properties, and deep-water variability on suborbital time scales and relating these observations to ice cores, we hope to better understand the forcing and dynamics of decadal- to millennial-scale climate variability in the North Atlantic-Arctic region. 


\section{PREVIOUS DSDP/ODP DRILLING AT HIGH NORTHERN LATITUDES}

Deep-ocean drilling has been conducted in the Nordic Seas during three previous legs. DSDP Leg 38 drilled a number of holes, but the rotary drilling and spot coring employed at that time left most questions related to the paleoenvironmental evolution unanswered. ODP Leg 104 drilled three holes on the Vøring Plateau, which provided the first detailed history of high-latitude climate evolution in the Neogene. Leg 151, the sister leg to Leg 162, drilled seven sites in the Nordic Seas and Yermak Plateau, greatly increasing our knowledge of the Cenozoic paleoenvironments at high latitudes.

Many DSDP and ODP legs have drilled sites in the open North Atlantic but only a few provide material for paleoceanographic studies. ODP Leg 105 drilled sites in the Baffin Bay/Labrador Sea area and provided new insight into high-latitude paleoenvironments on the American side of the high-latitude North Atlantic region. DSDP Legs 81 and 94 provided the first hydraulic-piston-cored sites in the North Atlantic, providing the first detailed records of climate variations in the late Neogene from the high latitudes. The first detailed records from the high-latitude North Pacific were recovered during ODP Leg 145. The reader is referred to the Initial Reports and Scientific Results volumes for these legs for a further documentation of their results.

During the Arctic summer of 1993, the JOIDES Resolution recovered the first scientific drill cores from the eastern Arctic Ocean, including material that records the long history of glacial climate in the Arctic and evidence for massive ice caps on the Arctic Ocean margin during certain glaciations (Myhre, Thiede, Firth, et al., 1995). During ODP Leg 151, drilling operations recovered over $3 \mathrm{~km}$ of core ranging in age from middle Eocene to Quaternary. Drilling at Site 907 on the Iceland Plateau recovered a middle Miocene to Holocene sequence overlying basement basalts with calcareous microfossils only in the upper Pliocene to Holocene, but with a middle to upper Miocene biosiliceous-rich interval indicating high-productivity conditions. Site 908 in the Fram Strait documented a late Oligocene age for the biosiliceous-rich prerifted strata on the Hovgård Ridge microcontinent. At nearby Site 909, drilling penetrated $1061.8 \mathrm{~m}$ into the Fram Strait basin, which today acts as the corridor for deep-water flow between the Arctic Ocean and Norwegian-Greenland Sea, and recovered a lower Miocene to Holocene sequence with variable coarse fraction and clay minerals with hydrocarbons at the bottom but virtually absent of calcareous and siliceous microfossils. Sites 910, 911, and 912 on the Yermak Plateau consist of Pliocene to Holocene glaciomarine sediments with abundant dropstones and high organic carbon content. Dating the inception of glaciomarine sedimentation was not achieved because sea ice drove the ship off site. The unfavorable ice conditions also prevailed during Leg 162, and no return to the Yermak Plateau sites could be attempted. Drilling at Site 913 on the East Greenland Margin recovered a thick section of Pliocene to Holocene glaciomarine sediments with abundant dropstones overlying a middle Eocene to lower Oligocene and middle Miocene sequence of clays and silty clays. A biosiliceous-rich interval occurs in the upper Eocene to lower Oligocene.

The oldest sediments recovered on Leg 151, middle Eocene at Site 913, contain the highest abundance of terrigenous organic matter recovered during Leg 151, and these sediments indicate the close proximity of a continental source during this initial phase of seafloor spreading in the Greenland Basin. The late Oligocene to earliest Miocene interval from Site 908 on the Hovgård Ridge suggests moderately well-mixed oceanic conditions in the Norwegian-Greenland Sea. Laminated-sediment intervals continued until about the middle/ late Miocene boundary (Sites 907, 909, and 913) and provide evidence for restricted circulation in the early Miocene NorwegianGreenland Sea. Leg 151 did not find evidence for deep-water flow from the Arctic or modern-type deep-water production in the Nordic Seas before this time.
Site 907 is rich in siliceous microfossils that appeared prior to the middle/late Miocene boundary but disappeared by about $7 \mathrm{Ma}$, when true Norwegian-Greenland Sea deep water may have begun to form. The disappearance of anoxic indicators close to the middle/late Miocene boundary at Site 909 may mark the start of deep mixing in the Greenland Basin, while the presence of siliceous production on the Iceland Plateau shows that the southern part of the Nordic Seas still had net upward transfers of nutrients from deeper waters to the surface, unlike modern conditions.

At all sites, the Pliocene and Pleistocene interval is marked by evidence of ice. Significant quantities of IRD appear near the late Miocene/Pliocene boundary and show a marked increase in abundance at about 2.9-2.72 Ma. Pliocene and Pleistocene sediments on the Yermak Plateau at the southern edge of the Arctic Ocean are extremely thick, deposited either by the melting of sediment-laden pack ice transported to the region by Arctic surface circulation, by ice melted from a massive Barents Sea Ice Sheet, or an ice cap centered on Svalbard. Site 910 was distinguished by a highly overconsolidated interval, below $25 \mathrm{mbsf}$ in the sediment column, presumably caused by an ice lobe of the Barents Sea Ice Sheet that reached well out to sea in the late Pleistocene and was grounded on the top of the Yermak Plateau. These event(s) occurred in the early Brunhes Chron (Flower, in press).

\section{DRILLING OBJECTIVES OF LEG 162}

Overall, our choice of sites on Leg 162 was guided by our two primary scientific objectives. First, we wanted to recover sequences with sedimentation rates high enough to delineate millennial-scale variability in lithologic, biologic, and geochemical characteristics. This goal was reached by the recovery of sedimentary sequences at five sites that had average accumulation rates higher than $10 \mathrm{~cm} / \mathrm{k} . \mathrm{y}$. These sites were located on sediment drifts in the North Atlantic or on rapidly accumulating continental margin regions in the Nordic Seas. Furthermore, we have been able to document continuous recovery over millions of years at almost all our sites. These sites - in particular, drift Sites 980, 981, 983, and 984 -have opened up a new window of exploration in the pelagic realm of the deep sea and will allow us, for the first time, to study the evolution of millennial-scale climate variability in the North Atlantic over millions of years. In particular, we will be able to evaluate the amplitude and frequency of millennial-scale variability during middle Pliocene intervals warmer than today.

Our second objective was to recover sites in a spatial array suitable for examining the evolution of vertical and horizontal gradients in water-mass properties. For instance, our North Atlantic sites form a depth transect in the northeastern basins spanning the depth interval of glacial intermediate water-mass formation (specific depths of sites: 982: 1150; 984: 1653; 983: 1977; and 980/981: $2157 \mathrm{~m}$ ). Likewise, two of the sites (983 and 984) are just downstream from the Iceland-Faeroe Ridge Overflows while the other sites (980 and 987) are just downstream from the Wyville-Thomson Ridge Overflow. This will allow us to examine the history of North Atlantic thermohaline circulation both on millennial and Milankovitch time scales. In addition, two of these sites, 981 at $2157 \mathrm{~m}$ and 982 at $1150 \mathrm{~m}$, extend back to the late Miocene and early middle Miocene, respectively. These records will allow us to examine the response of North Atlantic thermohaline circulation to tectonic changes in the sill depth of the Greenland-Scotland Ridge and the Isthmus of Panama, as well as the middle Miocene glaciation of Antarctica and the onset and evolution of small-scale Northern Hemisphere glaciation in the middle to late Miocene.

Our North Atlantic sites also form a northwest-southeast surfacewater transect across the major area of polar front movement on glacial-interglacial cycles. Thus, we should be able to compare east-west gradients in surface-water temperature and iceberg trajectories on 

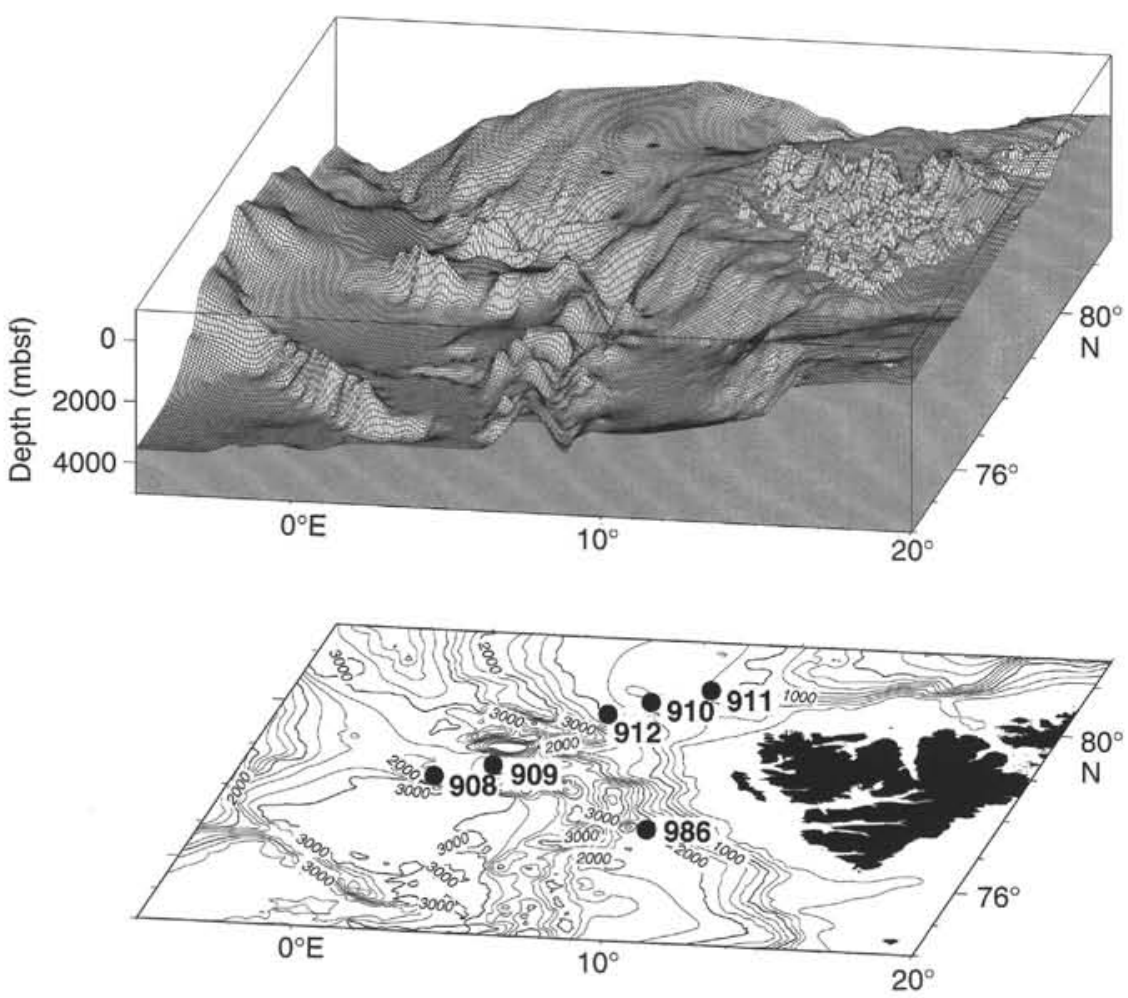

Figure 11. Detailed bathymetry of the Northern Gateway region showing locations of Sites 908, 909, 910, 911,912 , and 986 . Bathymetric data (in meters) from ETOPO5. suborbital time scales, further improving our understanding of the dynamics of Heinrich events and the even shorter Dansgaard-Oeschger events (e.g., Broecker, 1994; Bond et al., 1993, Fronval et al., 1995).

Lastly, Site 986 (SVAL-1B) was drilled on the Svalbard Margin (Fig. 11) to examine the onset of glaciation in the European Arctic and establish the history of the Svalbard-Barents Sea Ice Sheet, including a probable transition from a terrestrial to marine-based ice sheet in the Barents Sea. In the Pliocene-Pleistocene three major ice sheets have terminated along the margins of the Nordic Seas: the Greenland, Scandinavian, and Svalbard-Barents Sea Ice Sheets. Information on the inception, variability, and dynamics of these ice masses needs to be assessed individually for each ice sheet, in order to understand which areas are the most sensitive to early ice-sheet growth, when glaciation style shifted from mountain- and fjord-style glaciation to full-fledged ice sheets, and when marine-based ice sheets extending to the outer shelf area started to form. Drilling in relatively proximal areas of the ice masses is necessary to obtain this information. Sites 986 and 987 (EGM-4) are therefore located on the lower continental slope adjacent to the Svalbard-Barents and Greenland Ice Sheets, respectively.

The drill sites on the Iceland Plateau (907 and 985) and East Greenland Margin (987) are part of a paleoenvironmental transect from Norway to Greenland, designed to study the history of the advection of temperate, saline Atlantic waters into the Norwegian Sea (the "Nordic heat pump"). This transect covers the climatically sensitive gradient between polar areas near East Greenland to the temperate areas off Norway (Fig. 6). Sites drilled on the Vøring Plateau during ODP Leg 104 anchor the eastern end of the transect, and Site 987 on the Greenland continental margin forms its western end. By extending the late Pleistocene record available from piston cores back in time by ODP drilling, we will be able to obtain a clearer understanding of the relationships between the Nordic heat pump, ocean circulation patterns, and the glaciation history on Milankovitch time scales. This will provide insight into the climatic sensitivity of the Nordic Seas and their possible role as an early responder to orbital climate forcing.

The Leg 162 drilling schedule included 56 days at sea with drilling operations at eight sites. We began drilling on the sediment drifts south of Iceland, eventually moving northward to the Svalbard Margin, Fram Strait, and East Greenland Margin as sea ice retreated through the month of August. Overall, we recovered $6731 \mathrm{~m}$ of core and made over 1 million shipboard measurements. This material will lead to a better understanding of the role played by the high northern latitude seas in the global climate system on many time scales, and with these cores we expect to open a new frontier on ultra-high-resolution paleoceanography.

\section{ACKNOWLEDGMENTS}

We are grateful to our Leg 162 shipmates for scientific input, to the ODP technical support staff and Sedco drill crew, to the JOIDES planning groups and site proposers who helped to plan the leg, and to our Leg 151 co-chief colleagues for providing extensive background information on the tectonics of the Nordic Seas area.

\section{REFERENCES}

Aagaard, K., and Carmack, E.C., 1994. The Arctic Ocean and climate: a perspective. In Johannessen, O.M., Muensch, R.D., and Overland, J.E. (Eds.), The Polar Oceans and Their Role in Shaping the Global Environment. Geophys. Monogr., Maurice Ewing Ser., Am. Geophys. Union, $85: 5-20$.

Aagaard, K., Swift, J.H., and Carmack, E.C., 1985. Thermohaline circulation in the Arctic Mediterranean seas. J. Geophys. Res., 90:4833-4846.

Berger, W.H., and Jansen, E., 1994. Mid-Pleistocene climate shift: the Nansen connection. In Johannessen, O.M., Muensch, R.D., and Overland, J.E. (Eds.), The Role of the Polar Oceans in Shaping the Global Environment. Geophys. Monogr., Am. Geophys. Union, 85:295-311.

Berggren, W.A., and Schnitker, D., 1983. Cenozoic marine environments in the North Atlantic and Norwegian-Greenland Sea. In Bott, M.H.P., Saxov, S., Talwani, M., and Thiede, J. (Eds.), Structure and Development of the Greenland-Scotland Ridge. NATO Conf. Ser. IV, New York (Plenum), 495-548.

Bond, G., Broecker, W., Johnsen, S., McManus, J., Labeyrie, L., Jouzel, J., and Bonani, G., 1993. Correlations between climate records from the North Atlantic sediments and Greenland ice. Nature, 365:143-147.

Bond, G., Heinrich, H., Broecker, W., Labeyrie, L., McManus, J., Andrews, J., Huon, S., Janitschik, R., Clasen, S., Simet, C., Tedesco, K., Klas, M., Bonani, G., and Ivy, S., 1992. Evidence for massive discharge of ice- 
bergs into the North Atlantic ocean during the last glacial period. Nature, 360:245-249.

Bond, G.C., and Lotti, R., 1995. Iceberg discharges into the North Atlantic on millennial time scales during the last glaciation. Science, 276:10051010.

Bott, M.H.P., Saxov, S., Talwani, M., and Thiede, J. (Eds.), 1983. Structure and Development of the Greenland-Scotland Ridge. NATO Conf. Ser. IV: New York (Plenum).

Boyle, E.A., 1988. Vertical oceanic nutrient fractionation and glacial/interglacial $\mathrm{CO}_{2}$ cycles. Nature, 331:55-56.

Boyle, E.A., and Keigwin, L.D., 1987. North Atlantic thermohaline circulation during the past 20,000 years linked to high-latitude surface temperature. Nature, 330:35-40.

Brekke, H., and Riis, F., 1987. Tectonics and basin evolution of the Norwegian shelf between $62^{\circ} \mathrm{N}$ and $72^{\circ} \mathrm{N}$. Nor. Geol. Tidsskr., 67:295-321.

Broecker, W.S., 1994. Massive iceberg discharges as triggers for global climate change. Nature, 372:421-424.

Broecker, W.S., and Peng, T.-H., 1989. The cause of the glacial to interglacial atmospheric $\mathrm{CO}_{2}$ change: a polar alkalinity hypothesis. Global Biogeochem. Cycles, 3:215-239.

Broecker, W.S., Peteet, D.M., and Rind, D.H., 1985. Does the ocean-atmosphere system have more than one stable mode of operation? Nature, 315:21-26.

Carmack, E., and Aagaard, K., 1973. On the deep water of the Greenland Sea. Deep-Sea Res., 20:687-715.

Carter, L.D., Brigham-Grette, J., Marinkovich, L., Pease, V.L., and Hillhouse, J.W., 1986. Late Cenozoic Arctic Ocean sea ice and terrestrial paleoclimate. Geology, 14:675-678.

Clark, D.L., 1982. Origin, nature and world climate effect of Arctic Ocean ice-cover. Nature, 300:321-325.

Crane, K., Eldholm, O., Myhre, A.M., and Sundvor, E., 1982. Thermal implications for the evolution of the Spitsbergen transform fault. Tectonophysics, 89:1-32.

deMenocal, P.B., Ruddiman, W.F., and Pokras, E.M., 1993. Influence of high- and low-latitude on African terrestrial climate: Pleistocene eolian records from equatorial Atlantic Ocean Drilling Program Site 663. Paleoceanography, 8:209-242.

Dickson, R.R., Meincke, J., Malmberg, S.A., and Lee, A.J., 1988. The "great salinity anomaly" in the northern North Atlantic 1968-1982. Prog. Oceanogr., 20:103-151.

Doré, A.G., 1991. The structural foundation and evolution of Mesozoic seaways between Europe and the Arctic. Palaeogeogr., Palaeoclimatol., Palaeoecol., 87:441-492.

Einarsson, T., and Albertsson, K.J., 1988. The glacial history of Iceland during the past three million years. In Shackleton, N.J., West, R.G., and Bowen, D.Q. (Eds.), The Past Three Million Years: Evolution of Climatic Variability in the North Atlantic Region: Cambridge (Cambridge Univ, Press), 227-234.

Eldholm, O., 1990. Paleogene North Atlantic magmatic-tectonic events: environmental implications. Mem. Soc. Geol. Ital., 44:13-28.

Eldholm, O., Faleide, J.I., and Myhre, A.M., 1987. Continent-ocean transition at the western Barents Sea/Svalbard continental margin. Geology, 15:1118-1122.

Eldholm, O., Karasik, A.M., and Reksnes, P.A., 1990. The North American plate boundary. In Grantz, A., Johnson, G.L., and Sweeney, J.F. (Eds.), The Arctic Ocean Region. Geol. Soc. Am., Geol. of North Am. Ser., L:171-184.

Eldholm, O., Thiede, J., Taylor, E., et al., 1987. Proc. ODP, Init. Repts., 104: College Station, TX (Ocean Drilling Program).

Eldholm, O., and Thomas, E., 1993. Environmental impact of volcanic margin formation. Earth Planet. Sci. Lett., 117:319-329.

Faleide, J.I., Vågnes, E., and Gudlaugsson, S.T., 1992. Late Mesozoic-Cenozoic evolution of the southwestern Barents Sea in a regional rift-shear tectonic setting. Mar. Pet. Geol., 10:186-214.

Feden, R.H., Vogt, P.R., and Flemming, H.S., 1979. Magnetic and bathymetric evidence for the "Yermak" hot spot northwest of Svalbard in the Arctic Basin. Earth Planet. Sci. Lett., 44:18-38.

Flower, B.P., in press. Late Quaternary stable isotopic stratigraphy of Hole 910A, Yermak Plateau, Arctic Ocean: relations with Svalbard/Barents Sea ice-sheet history. In Thiede, J., Myhre, A.M., Firth, J.V., Johnson, G.L., and Ruddiman, W.F. (Eds.), Proc. ODP, Sci. Results, 151: College Station, TX (Ocean Drilling Program).

Fronval, T., and Jansen, E., in press. Late Neogene paleoclimates and paleoceanography in the Iceland-Norwegian Sea: evidence from the Iceland and Vøring Plateaus. In Thiede, J., Myhre, A.M., Firth, J.V., Johnson,
G.L., and Ruddiman, W.F. (Eds.), Proc, ODP, Sci. Results, 151: College Station, TX (Ocean Drilling Program).

Fronval, T., Jansen, E., Bloemendal, J., and Johnsen, S., 1995. Oceanic evidence for coherent fluctuations in Fennoscandian and Laurentide ice sheets on millennium timescales. Nature, 374:443-446.

Funder, S., Abrahamsen, N., Bennike, O., and Feyling-Hanssen, R.W., 1985. Forested Arctic: evidence from North Greenland. Geology, 13:542-546.

Gloersen, P., 1995. Modulation of hemispheric sea ice cover by ENSO events. Nature, 373:503-505.

GRIP [Greenland Ice-core Project] Members, 1993. Climate instability during the last interglacial period recorded in the GRIP ice core. Nature, 364:203-207.

Guest, P.S., and Davidson, K.L., 1991. Meteorological triggers for deep convection in the Greenland Sea. In Chu, P.C., and Gascard, J.C. (Eds.), Deep Convection and Deep Water Formation in the Oceans: New York (Elsevier), 369-375.

Häkkinen, S., 1987. Upwelling at the ice edge: a mechanism for deep water formation. J. Geophys. Res., 92:5031-5034.

Heinrich, H., 1988. Origin and consequences of cyclic ice rafting in the northeast Atlantic Ocean during the past 130,000 years. Quat. Res., $29: 142-152$

Henrich, R., 1989. Glacial/interglacial cycles in the Norwegian Sea: sedimentology, paleoceanography, and evolution of late Pliocene to Quaternary Northern Hemisphere climate. In Eldholm, O., Thiede, J., Taylor, E., et al., Proc. ODP, Sci. Results, 104: College Station, TX (Ocean Drilling Program), 189-232.

Henrich, R., Wolf, T., Bohrmann, G., and Thiede, J., 1989. Cenozoic paleoclimatic and paleoceanographic changes in the Northern Hemisphere revealed by variability of coarse-fraction composition in sediments from the Vøring Plateau-ODP Leg 104 drill sites. In Eldholm, O., Thiede, J., Taylor, E., et al., Proc. ODP, Sci. Results, 104: College Station, TX (Ocean Drilling Program), 75-188.

Herman, Y., and Hopkins, D.M., 1980. Arctic Ocean climate in late Cenozoic times. Science, 209:557-562.

Hinz, K., Meyer, H., and Miller, H., 1991. North-east Greenland Shelf north of $79^{\circ} \mathrm{N}$ : results of a reflection seismic experiment in sea ice. Mar. Pet. Geol., 8:461-467.

Holtedahl, H., 1993. Marine geology of the Norwegian Continental Margin. Nor. Geol. Unders. Spec. Publ., 6.

Imbrie, J., Berger, A., Boyle, E., Clemens, S., Duffy, A., Howard, W., Kukla, G., Kutzbach, J., Martinson, D., McIntyre, A., Mix, A., Molfino, B., Morley, J., Peterson, L., Pisias, N., Prell, W., Raymo, M., Shackleton, N., and Toggweiler, J., 1993. On the structure and origin of major glaciation cycles, 2 . The 100,000-year cycle. Paleoceanography, 8:699-735.

Imbrie, J., Boyle, E.A., Clemens, S.C., Duffy, A., Howard, W.R., Kukla, G., Kutzbach, J., Martinson, D.G., McIntyre, A., Mix, A.C., Molfino, B., Morley, J.J., Peterson, L.C., Pisias, N.G., Prell, W.L., Raymo, M.E., Shackleton, N.J., and Toggweiler, J.R., 1992. On the structure and origin of major glaciation cycles, 1. Linear responses to Milankovitch forcing. Paleoceanography, 7:701-738.

Jackson, H.R., Johnson, G.L., Sundvor, E., and Myhre, A.M., 1984. The Yermak Plateau: formed at a triple junction. J. Geophys. Res., 89:32233232.

Jansen, E., and Sjøholm, J., 1991. Reconstruction of glaciation over the past 6 Myr from ice-borne deposits in the Norwegian Sea. Nature, 349:600603.

Jones, E.J., Ewing, M., Ewing, J., and Eittreim, S., 1970. Influences of Norwegian Sea Overflow Water on sedimentation in the northern North Atlantic and Labrador Seas. J. Geophys. Res., 75:1655-1680.

Kidd, R.B., and Hill, P.R., 1987. Sedimentation on Feni and Gardar sediment drifts, In Ruddiman, W.F., Kidd, R.B., Thomas, E., et al., Init. Repts. DSDP, 94 (Pt. 2): Washington (U.S. Govt. Printing Office), 1217-1244.

Kristoffersen, Y., 1990. On the tectonic evolution and paleoceanographic significance of the Fram Strait gateway. In Bleil, U., and Thiede, J. (Eds.), Geological History of the Polar Oceans: Arctic versus Antarctic. NATO ASI Ser., Ser. C, 308:63-76.

Kushnir, Y., 1994. Interdecadal variations in North Atlantic sea surface temperature and associated atmospheric conditions. J. Clim., 7:141-156.

Larsen, B., 1983. Geology of the Greenland-Iceland Ridge in the Denmark Strait. In Bott, M.H.P., Saxov, S., Talwani, M., and Thiede, J. (Eds.), Structure and Development of the Greenland-Scotland Ridge. NATO Conf. Ser. IV: New York (Plenum), 425-444.

Larsen, H.C., Saunders, A.D., Clift, P.D., Beget, J., Wei, W., Spezzaferri, S., and the ODP Leg 152 Scientific Party, 1994. Seven million years of glaciation in Greenland. Science, 264:952-955. 
Larsen, V.B., 1987. A synthesis of tectonically related stratigraphy in the North Atlantic region from Aalenian to Cenomanian time. Nor. Geol. Tidsskr., 67:281-293.

Lawver, L.A., Müller, R.D., Srivastava, S.P., and Roest, W., 1990. The opening of the Arctic Ocean. In Bleil, U., and Thiede, J. (Eds.), Geological History of the Polar Oceans: Arctic versus Antarctic: Dordrecht (Kluwer Acad. Publ.), 29-62.

Locker, S., and Martini, E., 1989. Cenozoic silicoflagellates, ebridians, and actiniscidians from the Vøring Plateau (ODP Leg 104), In Eldholm, O., Thiede, J., Taylor, E., et al., Proc. ODP, Sci. Results, 104: College Station, TX (Ocean Drilling Program), 543-585.

McCartney, M.S., 1992. Recirculating components to the deep boundary current of the northern North Atlantic. Prog. Oceanogr., 29:283-383.

McCave, I.N., and Tucholke, B.E., 1986. Deep current-controlled sedimentation in the western North Atlantic. In Vogt, P.R., and Tucholke, B.E. (Eds.), The Western North Atlantic Region. Geol. Soc. Am., Geol. of North Am. Ser., M:451-468.

Miller, K.G., and Tucholke, B.E., 1983. Development of Cenozoic abyssal circulation south of the Greenland-Scotland Ridge. In Bott, M., Saxov, S., Talwani, M., and Thiede, J. (Eds.), Structure and Development of the Greenland-Scotland Ridge: New Methods and Concepts: New York (Plenum), 549-590.

Mudie, P.J., and Helgason, J., 1983. Palynological evidence for Miocene climatic cooling in eastern Iceland about 9.8 Myr ago. Nature, 303:689692.

Myhre, A.M., Eldholm, O., and Sundvor, E., 1982. The margin between Senja and Spitsbergen fracture zones: implication from plate tectonics. Tectonophysics, 89:33-50.

Myhre, A.M., Thiede, J., Firth, J.V., et al., 1995. Proc. ODP, Init. Repts., 151: College Station, TX (Ocean Drilling Program).

Nansen, F., 1906. Northern waters: Captain Roald Amundsen's oceanographic observations in the Arctic Seas in 1901, with a discussion of the origin of the bottom water of the Northern Seas. Videnskabs-Selskapets Skrifter. O-Mathematisk-Naturver. Klasse 1906, 3, 313.

Nelson, R.E., and Carter, L.D., 1985. Pollen analysis of a late Pliocene and early Pleistocene section from the Gubik Formation of Arctic Alaska. Quat. Res., 24:295-306.

Oppo, D.W., and Fairbanks, R.G., 1987. Variability in the deep and intermediate water circulation of the Atlantic Ocean during the past 25,000 years: Northern Hemisphere modulation of the Southern Ocean. Earth Planet. Sci. Lett., 86:1-15.

Oppo, D.W., Raymo, M.E., Lohmann, G.P., Mix, A.C., Wright, J.D., and Prell, W.L., 1995. $\delta^{13} \mathrm{C}$ record of upper North Atlantic deep water during the past 2.6 m.y. Paleoceanography, 10:373-394.

Paillard, D., and Labeyrie, L., 1994. Role of thermohaline circulation in the abrupt warming after Heinrich events. Nature, 372:162-164.

Peterson, W.H., and Rooth, C.G.H., 1976. Formation and exchange of deep water in the Greenland and Norwegian seas. Deep-Sea Res. Part A, 23:273-283.

Pisias, N.G., and Moore, T.C., Jr., 1981. The evolution of Pleistocene climate: a time series approach. Earth Planet. Sci. Lett., 52:450-458.

Pour, R.K., Fleming, H.S., Weber, J.R., Kristoffersen, Y., Hall, J.K., Grantz, A., and Johnson, G.L., 1985. Bathymetry of the Arctic Ocean (scale 1:6,000,000): Washington (Naval Research Laboratory).

Rahmstorf, S., 1994. Rapid climate transitions in a coupled ocean-atmosphere model. Nature, 372:82-85.

Raymo, M.E., 1992. Global climate change: a three million year perspective. In Kukla, G.J., and Went, E. (Eds.), Start of a Glacial. NATO ASI Ser. I: Berlin (Springer-Verlag), 3:207-223.

, 1994. The initiation of Northern Hemisphere glaciation. Annu. Rev. Earth Planet. Sci., 22:353-383.

Raymo, M.E., Hodell, D., and Jansen, E., 1992. Response of deep ocean circulation to initiation of Northern Hemisphere glaciation (3-2 Ma). Paleoceanography, 7:645-672.

Raymo, M.E., and Ruddiman, W.F., 1992. Tectonic forcing of late Cenozoic climate. Nature, 359:117-122.

Raymo, M.E., Ruddiman, W.F., Backman, J., Clement, B.M., and Martinson, D.G., 1989. Late Pliocene variation in Northern Hemisphere ice sheets and North Atlantic deep water circulation. Paleoceanography, 4:413446.

Raymo, M.E., Ruddiman, W.F., Shackleton, N.J., and Oppo, D.W., 1990. Evolution of Atlantic-Pacific $\delta^{13} \mathrm{C}$ gradients over the last 2.5 m.y.: evidence for decoupling of deep ocean circulation and global ice volume changes. Earth Planet. Sci. Lett., 97:353-368.
Repenning, C.A., Brouwers, E.M., Carter, L.D., Marincovitch, L., Jr., and Ager, T.A., 1987. The Beringian ancestry of Phenacomys (Rodentia: Cricetidae) and the beginning of the modern Arctic Ocean borderland biota. U.S. Geol. Surv. Bull., 1687:1-28.

Ruddiman, W.F., Kidd, R.B., Thomas, E., et al., 1987. Init. Repts. DSDP, 94 (Pts. 1 and 2): Washington (U.S. Govt. Printing Office).

Ruddiman, W.F., and Raymo, M.E., 1988. Northern hemisphere climatic regimes during the past $3 \mathrm{Ma}$ : possible tectonic connections. Philos. Trans. R. Soc. London B, 318:411-430.

Ruddiman, W.F., Raymo, M.E., Martinson, D.G., Clement, B.M., and Backman, J., 1989. Pleistocene evolution: Northern Hemisphere ice sheets and North Atlantic Ocean. Paleoceanography, 4:353-412.

Ruddiman, W.F., Raymo, M.E., and McIntyre, A., 1986. Matuyama 41,000year cycles: North Atlantic Ocean and Northern Hemisphere ice sheets. Earth Planet. Sci. Lett., 80:117-129.

Rudels, B., 1990. Haline convection in the Greenland Sea. Deep-Sea Res., 37:1491-1511.

Rudels, B., and Quadfasel, D., 1991. Convection and deep water formation in the Arctic Ocean-Greenland Sea system. J. Marine Syst, 2:435-450.

Rudels, B., Quadfasel, D., Friedrich, H., and Houssais, M.-N., 1989. Greenland Sea convection in winter of 1987-1988. J. Geophys. Res., 94:32233227.

Schlosser, P., Bonisch, G., Rhein, M., and Bayer, R. 1991. Reduction of deepwater formation in the Greenland Sea during the 1980s: evidence from tracer data. Science, 251:1054-1056.

Shackleton, N.J., Backman, J., Zimmerman, H., Kent, D.V., Hall, M.A., Roberts, D.G., Schnitker, D., Baldauf, J.G., Desprairies, A., Homrighausen, R., Huddlestun, P., Keene, J.B., Kaltenback, A.J., Krumsiek, K.A.O., Morton, A.C., Murray, J.W., and Westberg-Smith, J., 1984. Oxygen isotope calibration of the onset of ice-rafting and history of glaciation in the North Atlantic region. Nature, 307:620-623.

Simonsen, K., and Haugan, P.M., in press. Heat budgets of the Arctic Mediterranean and sea surface heat flux parametrizations for the Nordic Seas. J. Geophys. Res.

Spiegler, D., 1989. Ice-rafted Cretaceous and Tertiary fossils in PleistocenePliocene sediments, ODP Leg 104, Norwegian Sea. In Eldholm, O., Thiede, J., Taylor, E., et al., Proc. ODP, Sci. Results, 104: College Station, TX (Ocean Drilling Program), 739-744.

Sundvor, E., Johnson, G.L., and Myhre, A.M., 1982. Some aspects of morphology and structure of the Yermak Plateau, NW of Spitsbergen. Univ. Bergen, Seismol. Obs., Sci. Rep., 8.

Swift, J.H., 1980. Seasonal processes in the Iceland Sea, with special reference to their relationship to the Denmark Strait Overflow [Ph.D. thesis]. Univ. of Washington, Seattle.

Takahashi, T., Olafsson, J., Goddard, J.G., Chipman, D.W., and Sutherland, S.C., 1993. Seasonal variations of $\mathrm{CO}_{2}$ and nutrients in the high-latitude surface oceans: a comparative study. Global Biogeochem. Cycles, 7:843878.

Talwani, M., and Eldholm, O., 1977. Evolution of the Norwegian-Greenland Sea. Geol. Soc. Am. Bull., 88:969-999.

Thiede, J., 1983. Outstanding geological problems of the East GreenlandScotland Ridge: an introduction. In Bott, M.H.P., Saxov, S., Talwani, M., and Thiede, J. (Eds.), Structure and Development of Greenland-Scotland Ridge: New York (Plenum), 313-318.

Thiede, J., and Eldholm, O., 1983. Speculations about the paleo-depth of the Greenland-Scotland Ridge during late Mesozoic and Cenozoic times. In Bott, M.H.P., Saxov, S., Talwani, M., and Thiede, J. (Eds.), Structure and Development of Greenland-Scotland Ridge: New York (Plenum), 445-456.

Vogt, P.R., 1986a. Geophysical and geochemical signatures and plate tectonics. In Hurdle, B.G. (Ed.), The Nordic Seas: New York (Springer-Verlag), 413-662.

1986b. Seafloor topography, sediments, and paleoenvironments. In Hurdle, B.G. (Ed.), The Nordic Seas: New York (Springer-Verlag), $237-412$.

, 1983. The Iceland mantle plume: status of the hypothesis after a decade of new work. In Bott, M.H.P., Saxov, S., Talwani, M., and Thiede, J. (Eds.), Structure and Development of Greenland-Scotland Ridge: New Methods and Concepts: New York (Plenum), 191-213.

1971. Asthenosphere motion recorded by the ocean floor south of Iceland. Earth Planet. Sci. Lett., 13:153-160.

Warren, B.A., 1981. Deep circulation in the world ocean. In Warren, B.A., and Wunsch, C. (Eds.), Evolution of Physical Oceanography: Cambridge (MIT Press), 6-41. 
Watson, A.J., Nightingale, P.D., and Cooper, D.J., 1995. Modelling of atmospheric-ocean $\mathrm{CO}_{2}$ transfer. Philos. Trans. R. Soc. London B, 348:125132.

Weaver, A.J., and Hughes, T.M.C., 1994. Rapid interglacial climate fluctuations driven by North Atlantic ocean circulation. Nature, 367:447-450.

Wold, C., 1994. Cenozoic sediment accumulation on drifts in the northern North Atlantic. Paleoceanography, 9:917-941.

Wolf, T.C.W., and Thiede, J., 1991. History of terrigenous sedimentation during the past $10 \mathrm{~m} . \mathrm{y}$. in the North Atlantic (ODP Legs 104 and 105 and DSDP Leg 94). Mar. Geol., 101:83-102.

Woodruff, F., and Savin, S.M., 1989. Miocene deepwater oceanography. Paleoceanography, 4:87-140.
Wright, J.D., and Miller, K.G., 1993. Southern Ocean influences on late Eocene to Miocene deepwater circulation. Antarct. Res. Ser., 60:1-25.

Wright, J.D., Miller, K.G., and Fairbanks, R.G., 1991. Evolution of modern deepwater circulation: evidence from the late Miocene Southern Ocean. Paleoceanography, 6:275-290.

, 1992. Early and middle Miocene stable isotopes: implications for deepwater circulation and climate. Paleoceanography, 7:357-389.

Ziegler, P.A. (Ed.), 1988. Evolution of the Arctic-North Atlantic and the western Tethys. AAPG Mem., 43.

Ms 162IR-101 